\title{
Tandem Intramolecular Michael Addition-Aldol Reaction as a Tool for the Construction of the C-Ring of Hexacyclinic Acid.
}

\author{
Andriy Stelmakh, Timo Stellfeld ${ }^{\S}$ and Markus Kalesse* \\ Institut für Organische Chemie, Universität Hannover, \\ Schneiderberg 1 B, 30167 Hannover, Germany \\ * To whom correspondence should be sent. Phone: +49 (0)511 762-4688. \\ Fax: +49 (0)511 762-3011. E-mail : Markus.Kalesse@oci.uni-hannover.de

\section{Supporting Information}

\section{Table of Contents:}

General Methods

S2-S3

Experimental procedures and analytical data for 9, 10

S4-S5

(E)-ethyl 3-(2-(2-(2-methyl-1,3-dioxolan-2-yl)ethyl)cyclohexyl)-acrylate

S6

Experimental procedures and analytical data for 11, 12a, 12b, 13a, 14a, 14b

S7-S12

Copies of ${ }^{1} \mathrm{H}$ and ${ }^{13} \mathrm{C}$ NMR spectra for 9 :

S13-S14

Copy of 1H NMR-spectra for $\mathbf{1 0}$ :

Copies of ${ }^{1} \mathrm{H}$ and ${ }^{13} \mathrm{C}$ NMR spectra for

(E)-ethyl 3-(2-(2-(2-methyl-1,3-dioxolan-2-yl)ethyl)cyclohexyl)-acrylate

Copies of ${ }^{1} \mathrm{H}$ and ${ }^{13} \mathrm{C}$ NMR spectra for $\mathbf{1 1}$ :

S18-S19

Copies of ${ }^{1} \mathrm{H}$ and ${ }^{13} \mathrm{C}$ NMR spectra for 12a:

S20-S21

Copies of ${ }^{1} \mathrm{H}$ and ${ }^{13} \mathrm{C}$ NMR spectra for $\mathbf{1 2 b}$ :

S22-S23

Copies of nOe NMR spectra for $\mathbf{1 2 b}$ :

Copies of ${ }^{1} \mathrm{H}$ and ${ }^{13} \mathrm{C}$ NMR spectra for 13a:

Copies of ${ }^{1} \mathrm{H},{ }^{13} \mathrm{C}$ and nOe NMR spectra for $\mathbf{1 4 a}$

Copy of ${ }^{1} \mathrm{H}$ spectra of mixture of $\mathbf{1 3 b}$ and $\mathbf{1 4 b}$ :

\footnotetext{
${ }^{\S}$ Current address: Schering AG, Müllerstr. 178, 13342 Berlin, Germany.
} 
Copies of H,H COSY, HMQC and NOESY spectra for 12a:

S37-S39

Copies of H,H COSY, HMQC, HMBC and NOESY spectra for $\mathbf{1 2 b}$ :

S40-S43

Copies of H,H COSY, HMQC and NOESY spectra for 13a:

S44-S46

Copies of H,H COSY and HMQC spectra for 14a:

S47-S48

Copies of H,H COSY and HMQC and ROESY spectra for $\mathbf{1 4 b}$ :

S49-S51

\section{General Methods}

NMR spectra were recorded with Bruker AVS-500, AVS-400 or AM-200 spectrometers. Chemical shifts are reported in parts per million (ppm) relative to tetramethylsilane $(0.00$ ppm) on $\delta$-scale. Corresponding solvent signal served as an internal standard: for ${ }^{1} \mathrm{H}$ NMR spectra in $\mathrm{CDCl}_{3}$ - the singlet of $\mathrm{CHCl}_{3}$ at $\delta 7.26 \mathrm{ppm}$, in $\mathrm{C}_{6} \mathrm{D}_{6}$ - the singlet of $\mathrm{C}_{6} \mathrm{D}_{5} \mathrm{H}$ at $\delta 7.16$ ppm; for ${ }^{13} \mathrm{C}$ NMR spectra in $\mathrm{CDCl}_{3}$ - the triplet at $877.00 \mathrm{ppm}$, in $\mathrm{C}_{6} \mathrm{D}_{6}$ - the triplet at $\delta 128.40 \mathrm{ppm}$. Values of the coupling constant, $J$, are given in hertz $(\mathrm{Hz})$. To clarify the assignments of NMR-signals, the authors have numbered the carbon atoms of the structures. Following abbreviations are used in the experimental section for the description of ${ }^{1} \mathrm{H}-\mathrm{NMR}$ spectra: singlet (s), doublet (d), triplet (t), quartet (q), multiplet (m), doublet of doublets (dd), doublet of triplet (dt), doublet of quartets (dq), doublet of doublets of doublets (ddd), broad singlet (bs), broad doublet (bd) and broad triplet (bt). The chemical shifts of complex multiplets are given as the range of their occurrence. ${ }^{13} \mathrm{C}$-Signals were assigned by means of standard DEPT 135 and DEPT 90 experiments and the following abbreviations are used in the experimental part: quaternary $(\mathrm{Cq})$, methyne $(\mathrm{CH})$, methylene $\left(\mathrm{CH}_{2}\right)$ and methyl carbon atom $\left(\mathrm{CH}_{3}\right)$ respectively. Further assignment of NMR-signals was achieved using two-dimensional NMR experiments when appropriate (H,H-COSY, HMQC and HMBC).

Infrared spectra were recorded with Bruker 580 FT-IR photometer. Samples were solved in dichloromethane or applied neat according to the "Golden-Gate" ATR method.

High-resolution electrospray-mass spectra (HRMS-ESI) were recorded with Waters Micromass LCT spectrometer with a Lock-Spray unit.

Analytical gas chromatography (GC) was performed with HP 6890 device using MachereyNagel "Optima 5" capillary column (30 m, 5\% phenyl - 95\% dimethylpolysiloxan) and a flame ionization detector. Nitrogen served as the carrier gas. According to the standard method used, the column temperature was maintained $50{ }^{\circ} \mathrm{C}$ for $1 \mathrm{~min}$ then rose to $300{ }^{\circ} \mathrm{C}$ at a 
$20^{\circ} \mathrm{C} / \mathrm{min}$ rate and was maintained at $300{ }^{\circ} \mathrm{C}$ till the end of the run. The overall run time was $20 \mathrm{~min}$.

All air- and moisture sensitive reactions were performed under argon in heat gun-dried glassware.

All experiments were monitored by thin layer chromatography (TLC) performed on Merck 60 F-254 (0.2 mm thick) silica gel aluminium supported plates. Spots were visualized by exposure to ultraviolet light $(254 \mathrm{~nm})$ or by staining with a "vanillin reagent" $(85 \mathrm{~mL} \mathrm{MeOH}$, $5 \mathrm{~mL} \mathrm{H}_{2} \mathrm{SO}_{4}, 10 \mathrm{~mL} \mathrm{AcOH}, 0.5 \mathrm{~g}$ vanillin (added last)), “cer reagent" (10 g Ce( $\left(\mathrm{SO}_{4}\right)_{2}, 25 \mathrm{~g}$ phosphomolybdenic acid, $80 \mathrm{~mL} \mathrm{H}_{2} \mathrm{SO}_{4}, \mathrm{H}_{2} \mathrm{O}$ to $1000 \mathrm{~mL}$ ), followed by heating or by "permanganate reagent" ( $3 \mathrm{~g} \mathrm{KMnO}_{4}, 20 \mathrm{~g} \mathrm{~K}_{2} \mathrm{CO}_{3}, 5 \mathrm{ml} 5 \%$ aqueous $\mathrm{NaOH}, 300 \mathrm{~mL} \mathrm{H}_{2} \mathrm{O}$ ).

Tetrahydrofuran (THF) was distilled under argon from sodium/benzophenone. Dichloromethane was distilled from calcium hydride under argon.

Commercially available reagents were used as supplied.

Flash chromatography was performed with J. T. Baker brand silica gel $(40-60 \mu \mathrm{m}, 60 \AA$ pores). Eluents used for flash chromatography (usually $n$-hexane and ethyl acetate) were distilled prior to use. 
Trimethyl-(2-(2-(2-methyl-[1,3]dioxolan-2-yl)-ethyl)-cyclohexylidene-methoxy)-silane (9)

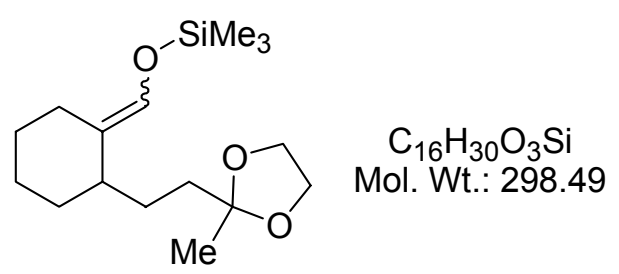

Mg turnings (1.10 g, $46 \mathrm{mmol}, 3 \mathrm{eq})$ were ground in a mortar and transferred immediately to a Schlenk flask fitted with an argon-filled balloon. THF $(3 \mathrm{~mL})$ was added. A solution of 2-(2bromoethyl)-2-methyl-1,3-dioxolane (2.92 g, $15 \mathrm{mmol}, 1 \mathrm{eq})$ and 1,2-dibromoethane (200 $\mathrm{mg}, 1.3 \mathrm{mmol})$ in THF ( $2 \mathrm{~mL})$ was added drop wise over 2 hours to $\mathrm{Mg}$ turnings while stirring at $22-24{ }^{\circ} \mathrm{C}$ (cooling in a water bath). After the addition was over, the reaction mixture was diluted with THF $(15 \mathrm{~mL})$ of and stirred for an hour at rt. The resulting grey solution was separated from the excess of $\mathrm{Mg}$ turnings and transferred with a syringe into another clean $100 \mathrm{~mL}$ Schlenk flask fitted with an argon-filled balloon. The flask was cooled to $-78{ }^{\circ} \mathrm{C}$ and the solution of $\mathrm{CuBr} \cdot \mathrm{Me}_{2} \mathrm{~S}(0.107 \mathrm{~g}, 0.5 \mathrm{mmol}, 3 \%$-mol $)$ in HMPA $(3.8 \mathrm{~mL}, 22$ mmol, 1.5 eq) was added. After the resulting mixture was stirred for an hour at $-78{ }^{\circ} \mathrm{C} \mathrm{a}$ mixture of 1-cyclohexene-1-carbaldehyde (929 mg, $8.44 \mathrm{mmol})$ and TMSCl (2.25 mL, 17 mmol) in THF $(10 \mathrm{~mL})$ was added within $8 \mathrm{~h}$ to the reaction mixture while stirring at $-78{ }^{\circ} \mathrm{C}$. The mixture was additionally stirred for 6 hours at $-78^{\circ} \mathrm{C}$. After that $\mathrm{Et}_{3} \mathrm{~N}(3 \mathrm{~mL})$ was added followed by hexane $(30 \mathrm{~mL})$ and $\mathrm{H}_{2} \mathrm{O}(30 \mathrm{~mL})$. Organic layer was separated. Aqueous layer was treated with saturated aqueous $\mathrm{NH}_{4} \mathrm{Cl}$ solution $(10 \mathrm{~mL})$ and extracted with hexane $(2 \times 30$ $\mathrm{mL}$ ). Combined hexane extract was washed with water and brine, dried over $\mathrm{MgSO}_{4}$ and concentrated. Flash chromatography on silica gel with hexane-AcOEt-Et ${ }_{3} \mathrm{~N}(100: 10: 1 \mathrm{v} / \mathrm{v} / \mathrm{v})$ gave $9(2.0 \mathrm{~g}, 80 \%)$ as a colorless oil.

${ }^{1} \mathbf{H}-\mathbf{N M R}\left(\mathbf{C}_{6} \mathbf{D}_{6}, 400 \mathrm{MHz}\right): \delta 6.19(\mathrm{~s}, 1 \mathrm{H}), 3.57(\mathrm{~s}, 4 \mathrm{H}), 2.60-2.45(\mathrm{~m}, 1 \mathrm{H}), 2.20(\mathrm{~m}, 1 \mathrm{H})$, 2.00-1.40 (m, 11H), $1.33(\mathrm{~s}, 3 \mathrm{H}), 0.11(\mathrm{~m}, 9 \mathrm{H})$.

${ }^{13}$ C-NMR (C $\left.\mathbf{C}_{6} \mathbf{D}_{6}, 100 \mathrm{MHz}\right): \delta 131.93(\mathrm{CH}), 125.03(\mathrm{Cq}), 111.02(\mathrm{Cq}), 65.35\left(\mathrm{CH}_{2}\right), 65.34$ $\left(\mathrm{CH}_{2}\right), 40.35(\mathrm{CH}), 38.66\left(\mathrm{CH}_{2}\right), 34.93\left(\mathrm{CH}_{2}\right), 28.49\left(\mathrm{CH}_{2}\right), 27.13\left(\mathrm{CH}_{2}\right), 24.84\left(\mathrm{CH}_{3}\right), 24.27$ $\left(\mathrm{CH}_{2}\right), 23.77\left(\mathrm{CH}_{2}\right), 0.17\left(3 \times \mathrm{CH}_{3}\right)$.

Elemental Analysis: Anal. C, 63.26\%; H, 9.944\%; calcd for $\mathrm{C}_{16} \mathrm{H}_{30} \mathrm{O}_{3} \mathrm{Si}$ : C, $64.38 \%$; H, $10.13 \%$. 


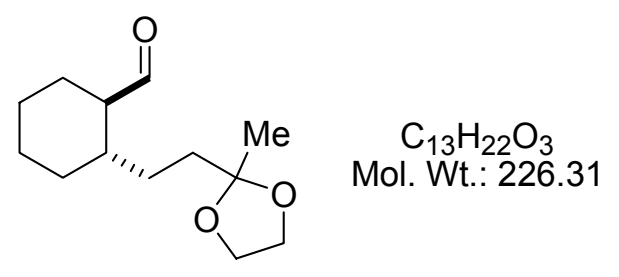

1.0M TBAF solution in THF ( $1 \mathrm{~mL}, 1.0 \mathrm{mmol}, 2.3 \mathrm{eq})$ was added to a solution of of 9 (130 $\mathrm{mg}, 0.44 \mathrm{mmol})$ in THF $(4 \mathrm{~mL})$. The reaction mixture was stirred at $\mathrm{rt}$ for 5 hours. It was then quenched with $\mathrm{H}_{2} \mathrm{O}(10 \mathrm{~mL})$, extracted with MTBE $(3 \times 10 \mathrm{~mL})$, the combined organic layers were washed with brine, dried over $\mathrm{MgSO}_{4}$, filtered and concentrated. Flash chromatography on silica gel with hexane-AcOEt (7:3 v/v) as eluent gave 10 as a colorless oil (53.2 $\mathrm{mg}, 54 \%)$. $\mathrm{R}_{\mathrm{f}}=0.3, \mathrm{R}_{\mathrm{f}}$ (silyl enolether) $=0.55$.

${ }^{1} \mathbf{H}-\mathbf{N M R}\left(\mathbf{C D C l}_{3}, \mathbf{2 0 0} \mathbf{M H z}\right): \delta 9.82$ (s), 9.55 (d, $\left.J=3.9 \mathrm{~Hz}, 1 \mathrm{H}\right), 3.92$ (m, 4H), 2.10-0.70 (complex m, 17H). The signals at $9.82(\mathrm{~s})$ and $9.55(\mathrm{~d}, J=3.9 \mathrm{~Hz}, 1 \mathrm{H}) \mathrm{ppm}$ correspond to the absorption of the $\mathrm{CHO}$ proton of the cis and the trans isomer respectively. According to the ${ }^{1} \mathrm{H}$ NMR spectrum the product was obtained as a 1:7.1 mixture of cis and trans isomers.

${ }^{13} \mathbf{C}-N M R\left(\mathbf{C}_{6} \mathbf{D}_{6}, 100 \mathrm{MHz}\right)$ for the cis:trans mixture: $\delta 204.62(\mathrm{CH}), 204.39(\mathrm{CH}), 110.70$ $(\mathrm{Cq}), 110.69(\mathrm{Cq}), 65.35\left(\mathrm{CH}_{2}\right), 65.32\left(\mathrm{CH}_{2}\right), 56.12(\mathrm{CH}), 52.58(\mathrm{CH}), 38.35\left(\mathrm{CH}_{2}\right), 38.32$ $\left(\mathrm{CH}_{2}\right), 38.18(\mathrm{CH}), 37.14(\mathrm{CH}), 37.06\left(\mathrm{CH}_{2}\right), 37.04\left(\mathrm{CH}_{2}\right), 31.04\left(\mathrm{CH}_{2}\right), 30.06\left(\mathrm{CH}_{2}\right), 29.51$ $\left(\mathrm{CH}_{2}\right), 26.67\left(\mathrm{CH}_{2}\right), 26.33\left(\mathrm{CH}_{2}\right), 25.99\left(\mathrm{CH}_{2}\right), 25.60\left(\mathrm{CH}_{2}\right), 25.17\left(\mathrm{CH}_{2}\right), 24.82\left(\mathrm{CH}_{2}\right), 24.68$ $\left(\mathrm{CH}_{3}\right), 24.67\left(\mathrm{CH}_{3}\right), 24.58\left(\mathrm{CH}_{2}\right)$.

HRMS ESI $m / z$ found: 227.1640 ; calcd for $(\mathrm{M}+\mathrm{H})^{+}: 227.1623$.

\section{Epimerization of 10.}

The solution of aldehyde $\mathbf{1 0}$ in hexane-AcOEt (6:1 v/v) was stirred with silica gel $(100 \mathrm{mg})$ for $24 \mathrm{~h}$ at $\mathrm{rt}$. The reaction mixture was filtered through a plug of cotton and concentrated to give the product. According to ${ }^{1} \mathrm{H}$ NMR the cis:tarns ratio was 1:8. 


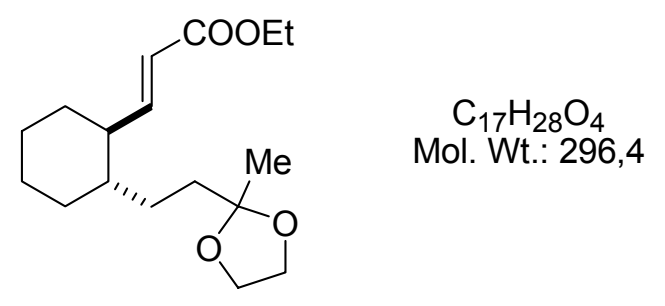

A solution of diethyl ethoxycarbonylmethanephosphonate $(688 \mathrm{mg}, 3.01 \mathrm{mmol}, 1.7 \mathrm{eq})$ in toluene $(3 \mathrm{~mL})$ was added at $\mathrm{rt}$ to a suspension of $\mathrm{NaH}$ in mineral oil $(60 \%, 106 \mathrm{mg}, 2.66$ mmol, $1.5 \mathrm{eq})$ in toluene $(4 \mathrm{~mL})$ forming a clear colorless solution which was additionally stirred for $20 \mathrm{~min}$ at $\mathrm{rt}$. The solution was cooled to $-20{ }^{\circ} \mathrm{C}$ and aldehyde $\mathbf{1 0}$ (400 $\mathrm{mg}, 1.77$ mmol, 1 eq) was added dropwise over $20 \mathrm{~min}$ as a solution in toluene $(4 \mathrm{~mL})$. The reaction mixture was stirred for $30 \mathrm{~min}$ at $-20{ }^{\circ} \mathrm{C}$. When the reaction was complete (TLC hexaneAcOEt $(7: 3 \mathrm{v} / \mathrm{v})$, product $\mathrm{R}_{\mathrm{f}}=0.45$, $\mathrm{UV}$ active), the reaction mixture was diluted with MTBE $(10 \mathrm{~mL})$ and $\mathrm{H}_{2} \mathrm{O}(10 \mathrm{~mL})$. It was extracted with MTBE $(3 \times 10 \mathrm{~mL})$ and the combined organic layers were washed with brine, dried over $\mathrm{MgSO}_{4}$, filtered and concentrated. Silica gel chromatography using hexane-AcOEt $(8: 2 \mathrm{v} / \mathrm{v})$ as eluent provides the desired product as a colorless oil (240 mg, 46\%).

${ }^{1} \mathbf{H}-\mathrm{NMR}\left(\mathbf{C D C l}_{3}, \mathbf{4 0 0} \mathbf{M H z}\right): \delta 6.38-6.77(\mathrm{dd}, J=9.5,15.7 \mathrm{~Hz}, 1 \mathrm{H}), 5.78(\mathrm{~d}, J=15.7 \mathrm{~Hz}$ $1 \mathrm{H}), 4.17(\mathrm{q}, J=7.2 \mathrm{~Hz}, 2 \mathrm{H}), 3.90(\mathrm{~m}, 4 \mathrm{H}), 1.90-0.80(\mathrm{~m})$. According to the ${ }^{1} \mathrm{H}$ NMR spectrum the product was obtained as a 1:6.6 mixture of isomers (cis/trans- in respect to the substitution pattern on the cyclohexane ring). Olefinic protons of the minor cis isomer are observed at 7.20-7.07 (dd, $J=8.9,15.7 \mathrm{~Hz})$ and $5.82(\mathrm{~d}, J=15.7 \mathrm{~Hz}) \mathrm{ppm}$.

${ }^{13}$ C-NMR (CDCl 3 , 100 MHz): $\delta 166.68(\mathrm{O}-\mathrm{C}=\mathrm{O}), 153.53(\mathrm{CH}), 120.62(\mathrm{CH}), 110.07(\mathrm{Cq})$, $64.47\left(\mathrm{CH}_{2}\right), 64.42\left(\mathrm{CH}_{2}\right), 59.99\left(\mathrm{CH}_{2}\right), 46.84(\mathrm{CH}), 40.97(\mathrm{CH}), 35.53\left(\mathrm{CH}_{2}\right), 32.62\left(\mathrm{CH}_{2}\right)$, $30.92\left(\mathrm{CH}_{2}\right), 28.60\left(\mathrm{CH}_{2}\right), 25.88\left(\mathrm{CH}_{2}\right), 25.48\left(\mathrm{CH}_{2}\right), 23.57\left(\mathrm{CH}_{3}\right), 14.17\left(\mathrm{CH}_{3}\right)$.

HRMS ESI $m / z$ found: 297.2070; calcd for $(\mathrm{M}+\mathrm{H})^{+}: 297.2066$.

IR ( $\mathrm{cm}^{-1}$, neat): 2981 (m), 2924 (s), 2854 (m), 1716 (s), 1650, 1447, 1370, 1323, 1263, 1223, $1174,1039,987,947,859,720$. 


\section{3-[2-(3-oxo-butyl)-cyclohexyl]-acrylic acid ethyl ester (11)}<smiles>CCOC(=O)C=C[C@H]1CCCC[C@@H]1CCC(C)=O</smiles>

$\mathrm{C}_{15} \mathrm{H}_{24} \mathrm{O}_{3}$

Mol. Wt.: 252,35

A solution of (E)-ethyl 3-(2-(2-(2-methyl-1,3-dioxolan-2-yl)ethyl)cyclohexyl)-acrylate (253 $\mathrm{mg}, 0.86 \mathrm{mmol}$ ) and pyridinium tosylate (PPTS) (64 mg, $0.256 \mathrm{mmol}, 30 \%$-mol) in aqueous acetone $\left(5 \mathrm{~mL}, 0.5 \mathrm{~mL} \mathrm{H}_{2} \mathrm{O}\right)$ was refluxed for $4 \mathrm{~h}$. When the reaction was complete (TLC hexane-AcOEt $(7: 3 \mathrm{v} / \mathrm{v})$, product $\mathrm{R}_{\mathrm{f}}=0.35$, $\mathrm{UV}$ active) the excess of the solvent was removed under reduced pressure, MTBE $(15 \mathrm{~mL})$ was added and the mixture was washed with saturated aqueous $\mathrm{NaHCO}_{3}$ solution and brine. The organic layer was dried over $\mathrm{MgSO}_{4}$, filtered and concentrated. The crude product was purified with flash chromatography on silica gel with hexane-AcOEt (8:2 v/v) as eluent to give 11 as a colorless oil (199 mg,(92\%).

${ }^{1}$ H-NMR (CDCl 3 , 400 MHz): $86.80-6.70(\mathrm{dd}, J=9.6,15.7 \mathrm{~Hz}, 1 \mathrm{H}), 5.81-5.72(\mathrm{~d}, J=15.6$ $\mathrm{Hz}, 1 \mathrm{H}), 4.18$ (q, J=7.1 Hz, 2H), 2.51-2.25 (m, 2H), 2.11 (s, 3H), 1.58 (s, 3H), 1.90-1.60 (m, $5 \mathrm{H}), 1.35-1.15(\mathrm{~m}, 8 \mathrm{H}), 1.00-0.80(\mathrm{~m}, 1 \mathrm{H})$. According to the ${ }^{1} \mathrm{H}$ NMR spectrum the product was obtained is a 1:6. mixture of isomers (cis/trans- in respect to the substitution pattern on the cyclohexane ring). Olefinic protons of the minor cis isomer are observed at: 7.14-7.08 (dd, $J=8.8,15.7 \mathrm{~Hz})$ and $5.83(\mathrm{~d}, J=15.7 \mathrm{~Hz}) \mathrm{ppm}$.

${ }^{13} \mathbf{C}-\mathrm{NMR}\left(\mathrm{CDCl}_{3}, \mathbf{1 0 0} \mathrm{MHz}\right): \delta 208.82(\mathrm{C}=\mathrm{O}), 166.55(\mathrm{O}-\mathrm{C}=\mathrm{O}), 153.00(\mathrm{CH}), 120.94(\mathrm{CH})$, $60.04\left(\mathrm{CH}_{2}\right), 46.83(\mathrm{CH}), 40.74\left(\mathrm{CH}_{2}\right), 40.48(\mathrm{CH}), 32.56\left(\mathrm{CH}_{2}\right), 30.80\left(\mathrm{CH}_{2}\right), 29.73\left(\mathrm{CH}_{3}\right)$, $28.33\left(\mathrm{CH}_{2}\right), 25.74\left(\mathrm{CH}_{2}\right), 25.34\left(\mathrm{CH}_{2}\right), 14.14\left(\mathrm{CH}_{3}\right)$.

HRMS ESI $m / z$ found: 275.1628; calcd for $(\mathrm{M}+\mathrm{Na})^{+}: 275.1623$.

IR (cm ${ }^{-1}$, neat): 2925 (s), 2854 (m), 1712 (s), 1650 (m), 1447, 1367, 1324, 1266, 1225, 1161, 1133, 1039, 986, 844, 734 .

Separation of the cis-trans 1:6 mixture was done on a $250 \times 25 \mathrm{~mm}$ "Reprosil-Pur $120 \mathrm{C} 18 \mathrm{AQ}$ $5 \mu \mathrm{m}$ " column with a $30 \times 20 \mathrm{~mm}$ "Reprosil-Pur $120 \mathrm{C} 18 \mathrm{AQ} 10 \mu \mathrm{m}$ " forecolumn and $\mathrm{CH}_{3} \mathrm{CN}-\mathrm{H}_{2} \mathrm{O}(48: 52 \mathrm{v} / \mathrm{v})$ as the eluent at $10 \mathrm{ml} / \mathrm{min}$ flow rate. Detection with $\mathrm{L}-7400$ "LaChrome" UV detector at $254 \mathrm{~nm}$. The minor diastereomer had a retention time of 57.0 min. The major one: $59.9 \mathrm{~min}$. In a single run $300 \mu \mathrm{L}$ of the solution of the diastereomeric mixture in $\mathrm{CH}_{3} \mathrm{CN}$, containing $60 \mathrm{mg}$ of the substance, was injected. 
Preparation of 12a (kinetic product)

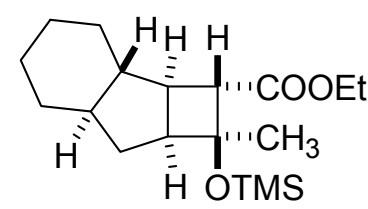

$\mathrm{C}_{18} \mathrm{H}_{32} \mathrm{O}_{3} \mathrm{Si}$

Mol. Wt.: 324,53

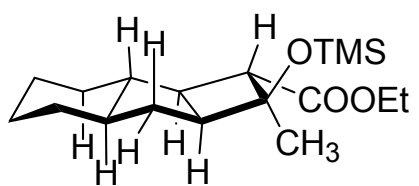

Rac

To a stirred solution of $11(83.0 \mathrm{mg}, 0.33 \mathrm{mmol}, 1 \mathrm{eq})$ and hexamethyldisilazane (104 $\mu 1,0.49$ mmol, 1.5 eq) in 1,2-dichloroethane ( $3.5 \mathrm{~mL})$ TMSI $(58 \mu 1,0.43 \mathrm{mmol}, 1.3 \mathrm{eq})$ was added dropwise at $-30{ }^{\circ} \mathrm{C}$. The mixture was stirred at this temperature for $3 \mathrm{~h}$. The reaction mixture was diluted with MTBE $(10 \mathrm{~mL})$ and saturated aqueous $\mathrm{NH}_{4} \mathrm{Cl}$ solution $(10 \mathrm{~mL})$ and the mixture was extracted with MTBE $(3 \times 10 \mathrm{~mL})$. Combined organic layers were washed with brine, dried over $\mathrm{MgSO}_{4}$ and concentrated. The crude product was purified with flash chromatography on silica gel $(20 \times 270 \mathrm{~mm}$ column $)$ with hexane-Et ${ }_{2} \mathrm{O}(50: 1 \mathrm{v} / \mathrm{v})$ as eluent to give 12a (56.6 mg, 53\%) as a colorless oil. According to the ${ }^{1} \mathrm{H}$ NMR the product is a 11:1 diastereomeric mixture. $R_{\mathrm{f}}=0.45-0.52$ in hexane-AcOEt $(10: 1 \mathrm{v} / \mathrm{v}) ; \mathrm{R}_{\mathrm{f}}=0.17-0.13$ in hexane$\mathrm{Et}_{2} \mathrm{O}(60: 1 \mathrm{v} / \mathrm{v})$.

${ }^{1} \mathbf{H}-\mathbf{N M R}\left(\mathbf{C}_{6} \mathbf{D}_{6}, 400 \mathrm{MHz}\right): \delta 4.03(\mathrm{dq}, J=3.8,7.2 \mathrm{~Hz}, 1 \mathrm{H}), 3.98(\mathrm{dq}, J=3.6,7.2 \mathrm{~Hz}, 1 \mathrm{H})$, 3.05-3.02 (d, $J=5,1 \mathrm{~Hz}, 1 \mathrm{H}), 2.45-2.31(\mathrm{~m}, 2 \mathrm{H}), 1.98-1.91(\mathrm{~m}, 1 \mathrm{H}), 1.87-1.81(\mathrm{~m}, 1 \mathrm{H}), 1.75-$ $1.62(\mathrm{~m}, 4 \mathrm{H}), 1.43(\mathrm{~s}, 3 \mathrm{H}), 1.14-1.06(\mathrm{~m}, 4 \mathrm{H}), 1.01-0.96(\mathrm{t}, J=7.2 \mathrm{~Hz}, 3 \mathrm{H}), 0.21(\mathrm{~s}, 9 \mathrm{H})$.

${ }^{13} \mathbf{C}-N M R\left(\mathbf{C}_{\mathbf{6}} \mathbf{D}_{\mathbf{6}}, \mathbf{1 0 0} \mathbf{M H z}\right): \delta 172.70(\mathrm{O}-\mathrm{C}=\mathrm{O}), 74.26(\mathrm{Cq}), 60.12(\mathrm{CH}), 59.99\left(\mathrm{CH}_{2}\right), 55.45$ $(\mathrm{CH}), 50.77(\mathrm{CH}), 49.40(\mathrm{CH}), 37.54(\mathrm{CH}), 32.95\left(\mathrm{CH}_{2}\right), 31.93\left(\mathrm{CH}_{2}\right), 31.92\left(\mathrm{CH}_{2}\right), 27.27$ $\left(\mathrm{CH}_{2}\right), 26.74\left(\mathrm{CH}_{3}\right), 26.62\left(\mathrm{CH}_{2}\right), 14.50\left(\mathrm{CH}_{3}\right), 2.14\left(3 \times \mathrm{CH}_{3}\right)$.

HRMS ESI $m / z$ found: $325.2394,388.2424$; calcd for $(\mathrm{M}+\mathrm{H})^{+} 325.2199,\left(\mathrm{M}+\mathrm{CH}_{3} \mathrm{CN}+\mathrm{Na}\right)^{+}$: 388.2284 
Preparation of $\mathbf{1 2 b}$ (thermodynamic product)

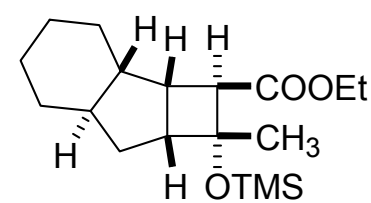

$\mathrm{C}_{18} \mathrm{H}_{32} \mathrm{O}_{3} \mathrm{Si}$

Mol. Wt.: 324,53

To a stirred solution of 11 (74.3 mg, $0.294 \mathrm{mmol}, 1.0$ eq) and $\mathrm{TMS}_{2} \mathrm{NH}$ (93 $\mu 1,0.442 \mathrm{mmol}$, $1.5 \mathrm{eq})$ in 1,2-dichloroethane ( $3 \mathrm{~mL}$ ) TMSI ( $52 \mu \mathrm{l}, 0.383 \mathrm{mmol}, 1.3 \mathrm{eq})$ was added dropwise at $0{ }^{\circ} \mathrm{C}$ and the mixture was stirred at this temperature for $24 \mathrm{~h}$. The reaction mixture was diluted with MTBE $(5 \mathrm{~mL})$, quenched with saturated aqueous $\mathrm{NH}_{4} \mathrm{Cl}$ solution $(5 \mathrm{~mL})$ and extracted with MTBE $(3 \times 10 \mathrm{~mL})$. Combined organic layers were washed with brine, dried over $\mathrm{MgSO}_{4}$ and concentrated. The crude product was purified with flash chromatography on silica gel $(25 \times 400 \mathrm{~mm}$ column $)$ with hexane- $\mathrm{Et}_{2} \mathrm{O}(60: 1 \mathrm{v} / \mathrm{v})$ as eluent to give $\mathbf{1 2 b}(59 \mathrm{mg}$, $62 \%$ ) as a colorless oil. The fractions was judged by GC. $\mathrm{R}_{\mathrm{f}}=0.45-0.50$ in hexane-AcOEt $(10: 1 \mathrm{v} / \mathrm{v}) ; \mathrm{R}_{\mathrm{f}}=0.15-0.12$ in hexane-Et $\mathrm{H}_{2} \mathrm{O}(60: 1 \mathrm{v} / \mathrm{v})$.

${ }^{1} \mathbf{H}-\mathbf{N M R}\left(\mathbf{C}_{6} \mathbf{D}_{6}, 400 \mathrm{MHz}\right): \delta 4.15(\mathrm{dq}, J=10.9,7.2 \mathrm{~Hz}, 1 \mathrm{H}), 4.08(\mathrm{dq}, J=10.9,7.2 \mathrm{~Hz}, 1 \mathrm{H})$, 3.01-2.97 (d, $J=6.8 \mathrm{~Hz}, 1 \mathrm{H}), 2.89-2.82(\mathrm{~m}, 1 \mathrm{H}), 2.36-2.31$ (t, $J=8.0 \mathrm{~Hz}, 1 \mathrm{H}), 2.20-2.13$ (dd, $J=12.8,6.3 \mathrm{~Hz}, 1 \mathrm{H}), 1.98-1.91(\mathrm{~m}, 1 \mathrm{H}), 1.71-1.62(\mathrm{~m}, 3 \mathrm{H}), 1.59-1.49$ (m, 1H), $1.45(\mathrm{~s}, 3 \mathrm{H})$, 1.16-1.12 (m, 5H), 1.02-0.97 (t, $J=7.2 \mathrm{~Hz}, 3 \mathrm{H}), 0.97-0.87(\mathrm{~m}, 1 \mathrm{H}), 0.24$ (s, 9H).

${ }^{13} \mathbf{C}-N M R\left(\mathbf{C}_{\mathbf{6}} \mathbf{D}_{\mathbf{6}}, \mathbf{1 0 0} \mathbf{M H z}\right)$ : $\delta 172.25(\mathrm{O}-\mathrm{C}=\mathrm{O}), 74.47(\mathrm{Cq}), 59.95\left(\mathrm{CH}_{2}\right), 50.97(\mathrm{CH}), 48.97$ $(\mathrm{CH}), 48.71(\mathrm{CH}), 43.30(\mathrm{CH}), 37.16(\mathrm{CH}), 32.33\left(\mathrm{CH}_{2}\right), 32.32\left(\mathrm{CH}_{2}\right), 27.05\left(\mathrm{CH}_{2}\right), 26.92$ $\left(\mathrm{CH}_{2}\right), 26.90\left(\mathrm{CH}_{3}\right), 26.58\left(\mathrm{CH}_{2}\right), 14.49\left(\mathrm{CH}_{3}\right), 2.14\left(3 \times \mathrm{CH}_{3}\right)$.

HRMS ESI $m / z$ found: $325.2191,388.2304$; calcd for $(\mathrm{M}+\mathrm{H})^{+}: 325.2199,\left(\mathrm{M}+\mathrm{CH}_{3} \mathrm{CN}+\mathrm{Na}\right)^{+}$: 388.2284 . 


\section{Preparation of 13a}

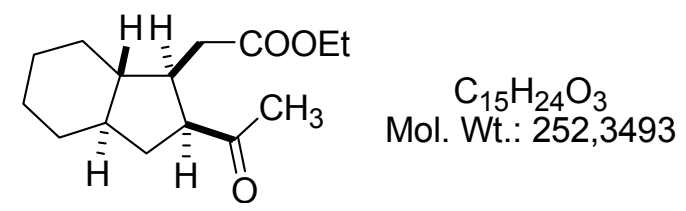

The solution of silyl ether 12a $(69.6 \mathrm{mg}, 0.214 \mathrm{mmol})$ in THF $(5 \mathrm{~mL})$ was cooled to $-30{ }^{\circ} \mathrm{C}$ and $1.0 \mathrm{M}$ solution of TBAF in THF $(0.214 \mathrm{mmol}, 0.214 \mathrm{~mL})$ was added. The reaction mixture was stirred for 30 min at $-30{ }^{\circ} \mathrm{C}$, quenched with saturated aqueous $\mathrm{NH}_{4} \mathrm{Cl}$ solution $(5$ $\mathrm{mL})$ and extracted with MTBE $(3 \times 10 \mathrm{~mL})$. The combined organic layers were washed with brine, dried over $\mathrm{MgSO}_{4}$ and concentrated. The crude product was purified with flash chromatography on silica gel $(20 \times 240 \mathrm{~mm}$ column $)$ with hexane-AcOEt $(20: 1 \mathrm{v} / \mathrm{v})$ as eluent to give $13 \mathbf{a}(43.2 \mathrm{mg}, 80 \%)$ as a colorless oil.

${ }^{1} \mathbf{H}-\mathbf{N M R}\left(\mathbf{C D C l}_{3}, \mathbf{5 0 0} \mathbf{M H z}\right): \delta 4.07$ (q, $\left.J=7.1 \mathrm{~Hz}, 2 \mathrm{H}\right), 3.36(\mathrm{ddd}, J=8.7,8.7$ and $8.7 \mathrm{~Hz}$, 1H), 2.56 (dd, $J=16.9,10.8 \mathrm{~Hz}, 1 \mathrm{H}), 2.41$ (dd, $J=16.9,4.7 \mathrm{~Hz}, 1 \mathrm{H}), 2.13$ (s, 3H), 2.07 (ddd, $J=8.7,11.7$ and $6.0 \mathrm{~Hz}, 1 \mathrm{H}), 1.97(\mathrm{ddd}, J=20.7,11.1$ and $4.7 \mathrm{~Hz}, 1 \mathrm{H}), 1.86-1.80(\mathrm{~m}, 1 \mathrm{H})$, 1.79-1.70 (m, 3H), 1.22 (t, $J=7.1 \mathrm{~Hz}, 3 \mathrm{H}), 1.27-1.11$ (m, 4H), 1.04 (dddd, $J=11.3,11.2$, 11.3, 3.1 Hz, 1H), 1.05-0.96 (m, 1H), 0.90-0.81 (m, 1H).

${ }^{13}$ C-NMR (CDCl 3 , 100 MHz): $\delta 213.38(\mathrm{Cq}), 173.91(\mathrm{Cq}), 60.20\left(\mathrm{CH}_{2}\right), 50.04(\mathrm{CH}), 49.88$ $(\mathrm{CH}), 45.53(\mathrm{CH}), 43.71(\mathrm{CH}), 36.33\left(\mathrm{CH}_{2}\right), 33.40\left(\mathrm{CH}_{2}\right), 32.04\left(\mathrm{CH}_{3}\right), 31.51\left(\mathrm{CH}_{2}\right), 30.09$ $\left(\mathrm{CH}_{2}\right), 26.24\left(\mathrm{CH}_{2}\right), 25.83\left(\mathrm{CH}_{2}\right), 14.18\left(\mathrm{CH}_{3}\right)$.

HRMS ESI $m / z$ found: 275.1636, 316.1883; calcd for $(\mathrm{M}+\mathrm{Na})^{+}:$275.1623, $\left(\mathrm{M}+\mathrm{CH}_{3} \mathrm{CN}+\mathrm{Na}\right)^{+}: 316,1889$. 


\section{Preparation of 14a}

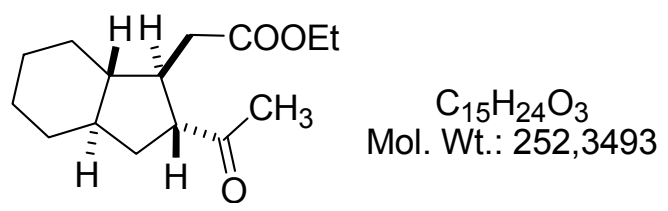

1.0M solution of TBAF in THF $(0.55 \mathrm{~mL}, 0.55 \mathrm{mmol})$ was added to the solution of methyl ketone 13a $(27.9 \mathrm{mg}, 0.111 \mathrm{mmol})$ in THF $(5 \mathrm{~mL})$ at $\mathrm{rt}$. After $3 \mathrm{~h}$ the reaction mixture was quenched with saturated aqueous $\mathrm{NH}_{4} \mathrm{Cl}$ solution and extracted with AcOEt $(3 \times 10 \mathrm{~mL})$. The combined organic layers were washed with brine, dried over $\mathrm{MgSO}_{4}$ and concentrated. The crude product was purified with flash chromatography on silica gel $(160 \times 15 \mathrm{~mm}$ column $)$ with hexane-AcOEt $(10: 1 \mathrm{v} / \mathrm{v})$ as eluent to give $\mathbf{1 4 a}(15 \mathrm{mg}, 54 \%)$ as a colorless oil.

${ }^{1}$ H-NMR (CDCl 3 , 500 MHz): $\delta 4.06$ (q, $\left.J=7.2 \mathrm{~Hz}, 2 \mathrm{H}\right), 2.76(\mathrm{ddd}, J=11.5,7.6,3.0 \mathrm{~Hz}$, 1H), 2.49 (dd, $J=14.3,4.3 \mathrm{~Hz}, 1 \mathrm{H}), 2.23$ (dddd, $J=10.9,7.3,9.2$ and 4.2 Hz, 1H), 2.17 (s, $3 \mathrm{H}) 2.16(\mathrm{dd}, J=14.4,9.2 \mathrm{~Hz}, 1 \mathrm{H}), 1.85-1.75(\mathrm{~m}, 2 \mathrm{H}), 1.75(\mathrm{ddd}, J=12.7,7.0$ and $2.9 \mathrm{~Hz}$, $1 \mathrm{H}), 1.75-1.65$ (m, 2H), $1.51(\mathrm{ddd}, J=12.3,12.1,12.1 \mathrm{~Hz}, 1 \mathrm{H}), 1.29$ (t, $J=7.2 \mathrm{~Hz}, 3 \mathrm{H}), 1.30$ $1.20(\mathrm{~m}, 1 \mathrm{H}), 1.20-1.10(\mathrm{~m}, 2 \mathrm{H}), 1.10-1.00(\mathrm{~m}, 1 \mathrm{H}), 0.85-0.99(\mathrm{~m}, 1 \mathrm{H}), 0.83$ (dddd, $J=11.1$, $11.1,11.1$ and $3.3 \mathrm{~Hz}, 1 \mathrm{H})$.

${ }^{13} \mathbf{C}-\mathbf{N M R}\left(\mathrm{CDCl}_{3}, \mathbf{1 0 0} \mathrm{MHz}\right): \delta 210.76(\mathrm{Cq}), 172.94(\mathrm{Cq}), 60.31\left(\mathrm{CH}_{2}\right), 55.40(\mathrm{CH}), 51.72$ $(\mathrm{CH}), 44.52(\mathrm{CH}), 42.95(\mathrm{CH}), 37.87\left(\mathrm{CH}_{2}\right), 34.71\left(\mathrm{CH}_{2}\right), 31.49\left(\mathrm{CH}_{2}\right), 29.86\left(\mathrm{CH}_{2}\right), 29.07$ $\left(\mathrm{CH}_{3}\right), 25.95\left(\mathrm{CH}_{2}\right), 25.92\left(\mathrm{CH}_{2}\right), 14.15\left(\mathrm{CH}_{3}\right)$.

HRMS ESI $\mathrm{m} / \mathrm{z}$ found: 253.1742, 275.1669, 316.1901; calcd for $(\mathrm{M}+\mathrm{H})^{+}: 253.1798$, $(\mathrm{M}+\mathrm{Na})^{+}: 275.1618,\left(\mathrm{M}+\mathrm{CH}_{3} \mathrm{CN}+\mathrm{Na}\right)^{+}: 316.1889$. 


\section{Preparation of 14b}

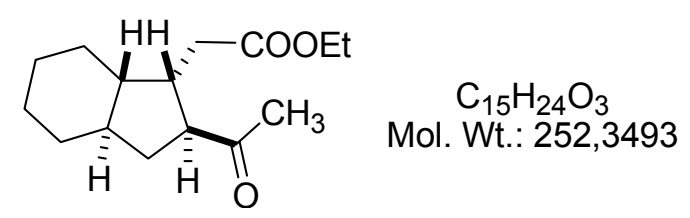

1.0M TBAF solution in THF $(0.066 \mathrm{~mL}, 0.066 \mathrm{mmol}, 1.0 \mathrm{eq})$ was added to the solution of 12b (21.5 mg, $0.066 \mathrm{mmol})$ in $\mathrm{THF}(5 \mathrm{~mL})$ at $-30{ }^{\circ} \mathrm{C}$. The reaction mixture was stirred at -30 ${ }^{\circ} \mathrm{C}$ for $30 \mathrm{~min}$, then quenched while cold with saturated aqueous $\mathrm{NH}_{4} \mathrm{Cl}$ solution $(5 \mathrm{~mL})$, MTBE $(5 \mathrm{~mL})$ and $\mathrm{H}_{2} \mathrm{O}(5 \mathrm{~mL})$. The reaction mixture was extracted with MTBE $(3 \times 10 \mathrm{~mL})$. Combined extract was washed with brine, dried over $\mathrm{MgSO}_{4}$, concentrated. After flash chromatographic purification (hexane-AcOEt $\left.(8: 1 \mathrm{v} / \mathrm{v}), \mathrm{R}_{\mathrm{f}}=0.17-0.20\right) 13.2 \mathrm{mg}(79 \%)$ of a colorless oil was obtained. According to $1 \mathrm{H}$ NMR the product was a 2.8:1.0 diastereomeric mixture. The signals of the $\mathrm{CH}_{3}$ group are found at $\delta 1.91 \mathrm{ppm}$ and $\delta 1.93 \mathrm{ppm}$, respectively (in $\left.\mathrm{C}_{6} \mathrm{D}_{6}\right)$.

1.0M TBAF solution in THF $(0.13 \mathrm{~mL}, 0.13 \mathrm{mmol}, 3 \mathrm{eq})$ was added to the solution of the above 2.8:1.0 diastereomeric mixture $(11.0 \mathrm{mg}, 0.044 \mathrm{mmol})$ in THF $(9 \mathrm{~mL})$ at $\mathrm{rt}$. After $3 \mathrm{~h}$ at rt the reaction mixture was quenched with saturated aqueous $\mathrm{NH}_{4} \mathrm{Cl}$ solution $(5 \mathrm{~mL})$ and extracted with AcOEt $(3 \times 10 \mathrm{~mL})$. Combined extract was washed with brine, dried over $\mathrm{MgSO}_{4}$ and concentrated. The crude product was purified with flash chromatography on silica gel with hexane-AcOEt $(8: 1 \mathrm{v} / \mathrm{v}), \mathrm{R}_{\mathrm{f}}=0.17-0.20$ to give $\mathbf{1 4 b}(6.7 \mathrm{mg}, 61 \%)$ as a colorless oil. According to $1 \mathrm{H}$ NMR the product is a single diastereomer with the chemical shift of the $\mathrm{CH}_{3}$ group at $\delta 1.93 \mathrm{ppm}\left(\right.$ in $\left.\mathrm{C}_{6} \mathrm{D}_{6}\right)$.

${ }^{1} \mathbf{H}-\mathbf{N M R}\left(\mathbf{C}_{\mathbf{6}} \mathbf{D}_{\mathbf{6}}, \mathbf{5 0 0} \mathbf{M H z}\right): \delta 3.96(\mathrm{q}, J=7.1,1 \mathrm{H}), 3.95$ (q, $\left.J=7.1,1 \mathrm{H}\right), 2.88(\mathrm{dddd}, J=2.9$, $5.2,10.9,8.2 \mathrm{~Hz}, 1 \mathrm{H}), 2.49(\mathrm{ddd}, J=3.2,8.7,8.7 \mathrm{~Hz}, 1 \mathrm{H}), 2.21(\mathrm{dd}, J=5.2,15.2 \mathrm{~Hz}, 1 \mathrm{H})$, $1.93(\mathrm{~s}, 3 \mathrm{H}), 1.85(\mathrm{dd}, J=10.9,15.2 \mathrm{~Hz}, 1 \mathrm{H}), 1.73-1.68(\mathrm{~m}, 1 \mathrm{H}), 1.65$ (ddd, $J=6.2,8.5,12.1$ Hz, 1H), 1.61-1.53 (m, 2H), $1.48-1.42(\mathrm{~m}, 1 \mathrm{H}), 1.19$ (ddd, $J=11.8,11.8,9.0 \mathrm{~Hz}, 1 \mathrm{H}), 1.20$ $1.13(\mathrm{~m}, 1 \mathrm{H}), 0.98(\mathrm{t}, J=7.1 \mathrm{~Hz}, 3 \mathrm{H}), 0.97-0.90(\mathrm{~m}, 2 \mathrm{H}), 0.96-0.88(\mathrm{~m}, 1 \mathrm{H}), 0.81(\mathrm{~m}, 1 \mathrm{H})$, 0.75 (dddd, $J=2.6,11.3,13.0,12.2 \mathrm{~Hz}, 1 \mathrm{H}$ ).

${ }^{13}$ C-NMR (C $\left.\mathbf{C}_{6} \mathbf{D}_{6}, 125 \mathrm{MHz}\right): \delta 208.26(\mathrm{C}=\mathrm{O}), 173.12(\mathrm{O}-\mathrm{C}=\mathrm{O}), 60.54\left(\mathrm{CH}_{2}\right), 56.95(\mathrm{CH})$, $48.16(\mathrm{CH}), 43.41(\mathrm{CH}), 39.97(\mathrm{CH}), 36.86\left(\mathrm{CH}_{2}\right), 35.93\left(\mathrm{CH}_{2}\right), 32.49\left(\mathrm{CH}_{2}\right), 29.12\left(\mathrm{CH}_{3}\right)$, $28.05\left(\mathrm{CH}_{2}\right), 26.80\left(\mathrm{CH}_{2}\right), 26.64\left(\mathrm{CH}_{2}\right), 14.64\left(\mathrm{CH}_{3}\right)$.

HRMS ESI $m / z$ found: 275.1653, 316.1885; calcd for $(\mathrm{M}+\mathrm{Na})^{+}:$275.1623, $\left(\mathrm{M}+\mathrm{CH}_{3} \mathrm{CN}+\mathrm{Na}\right)^{+}: 316.1889$. 


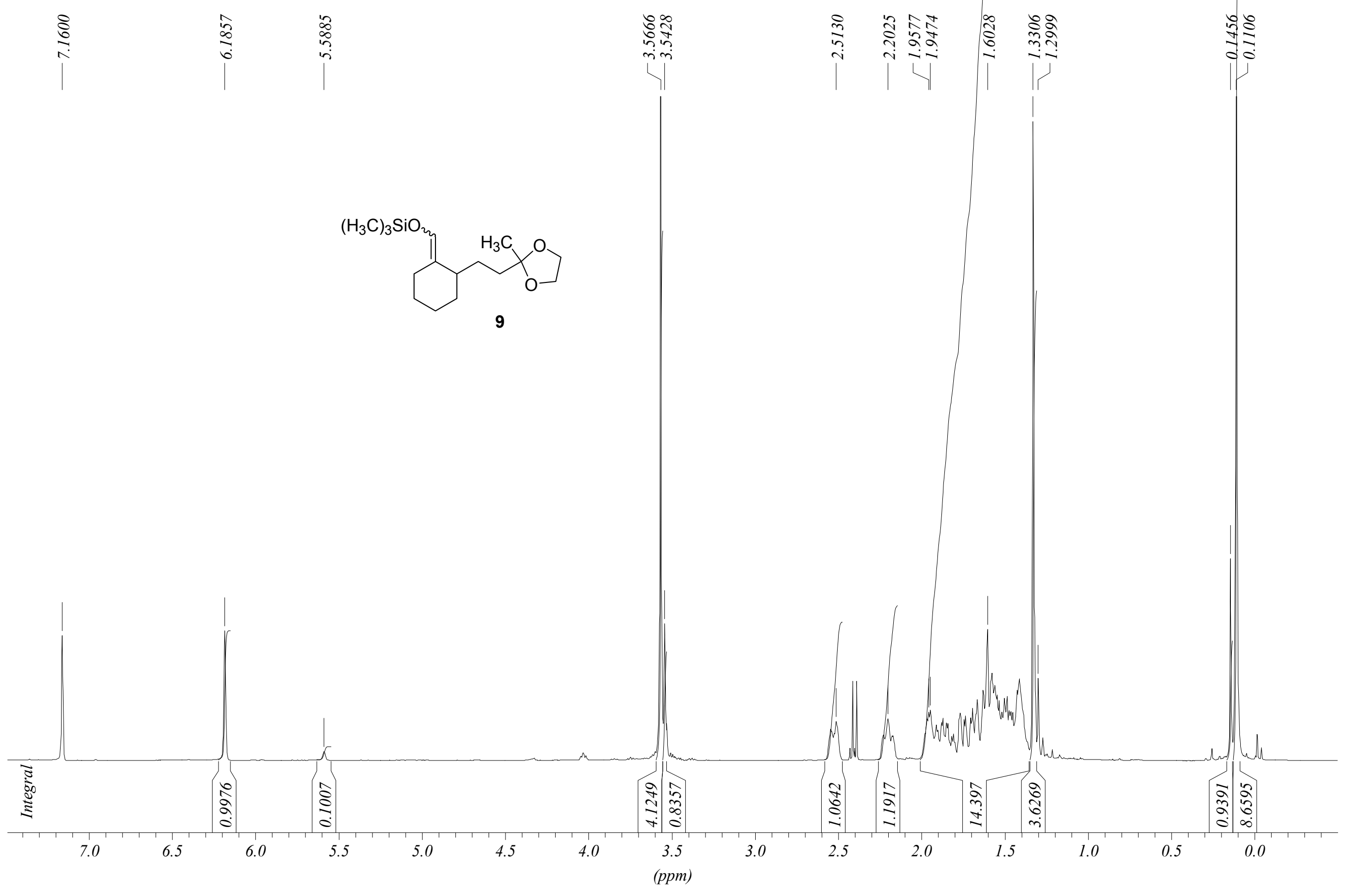




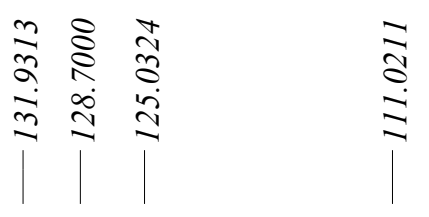

ํํำ

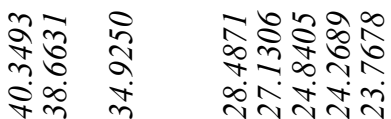

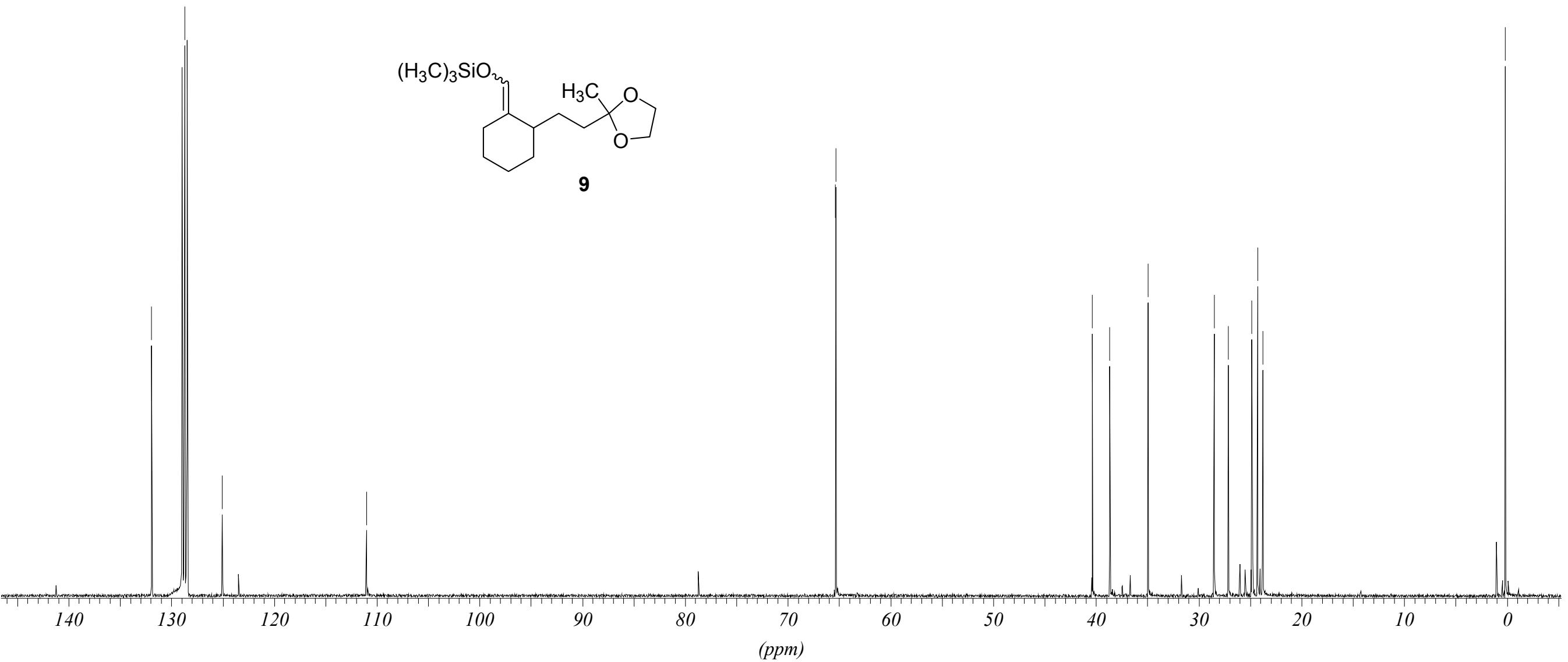




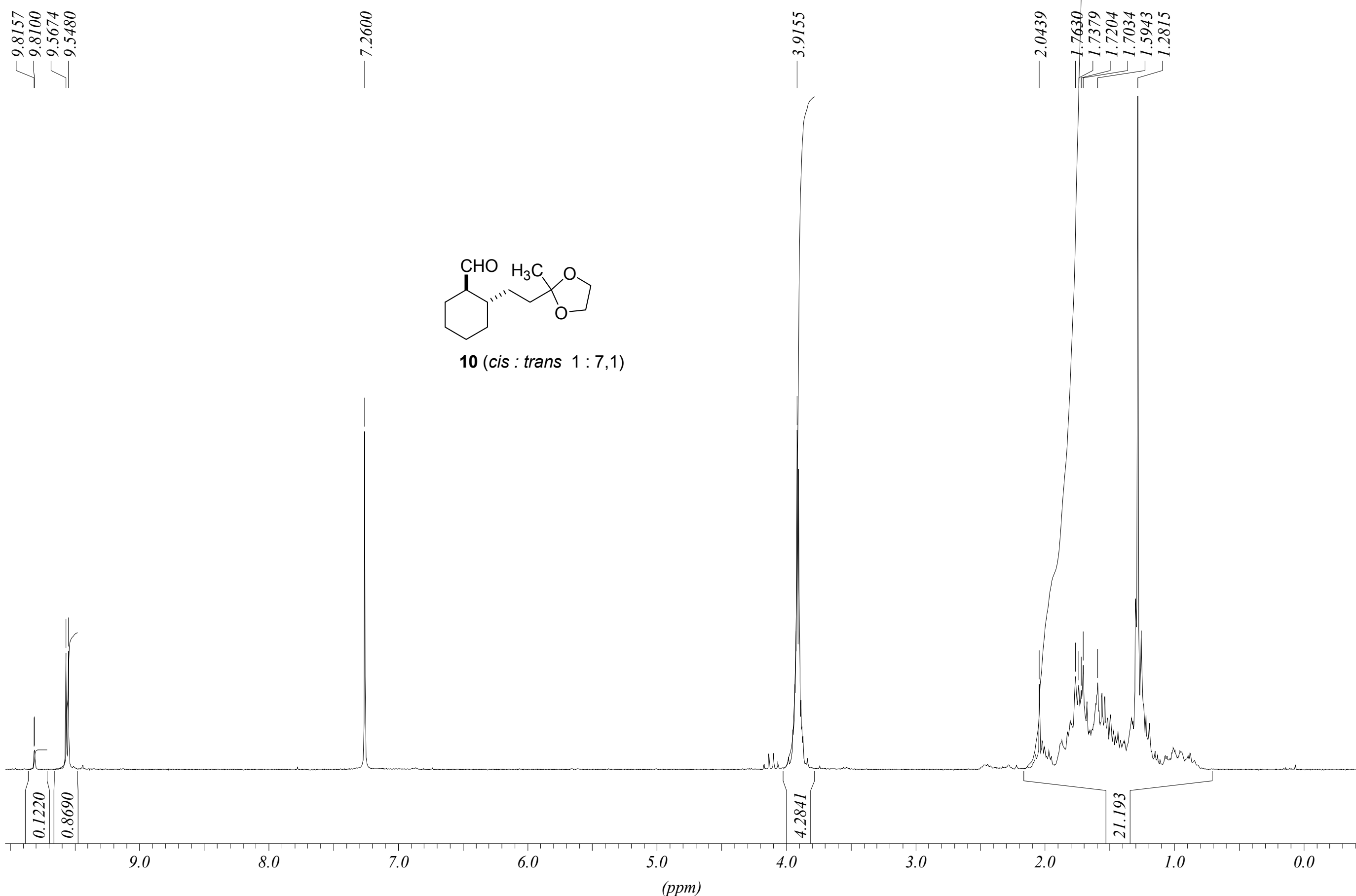




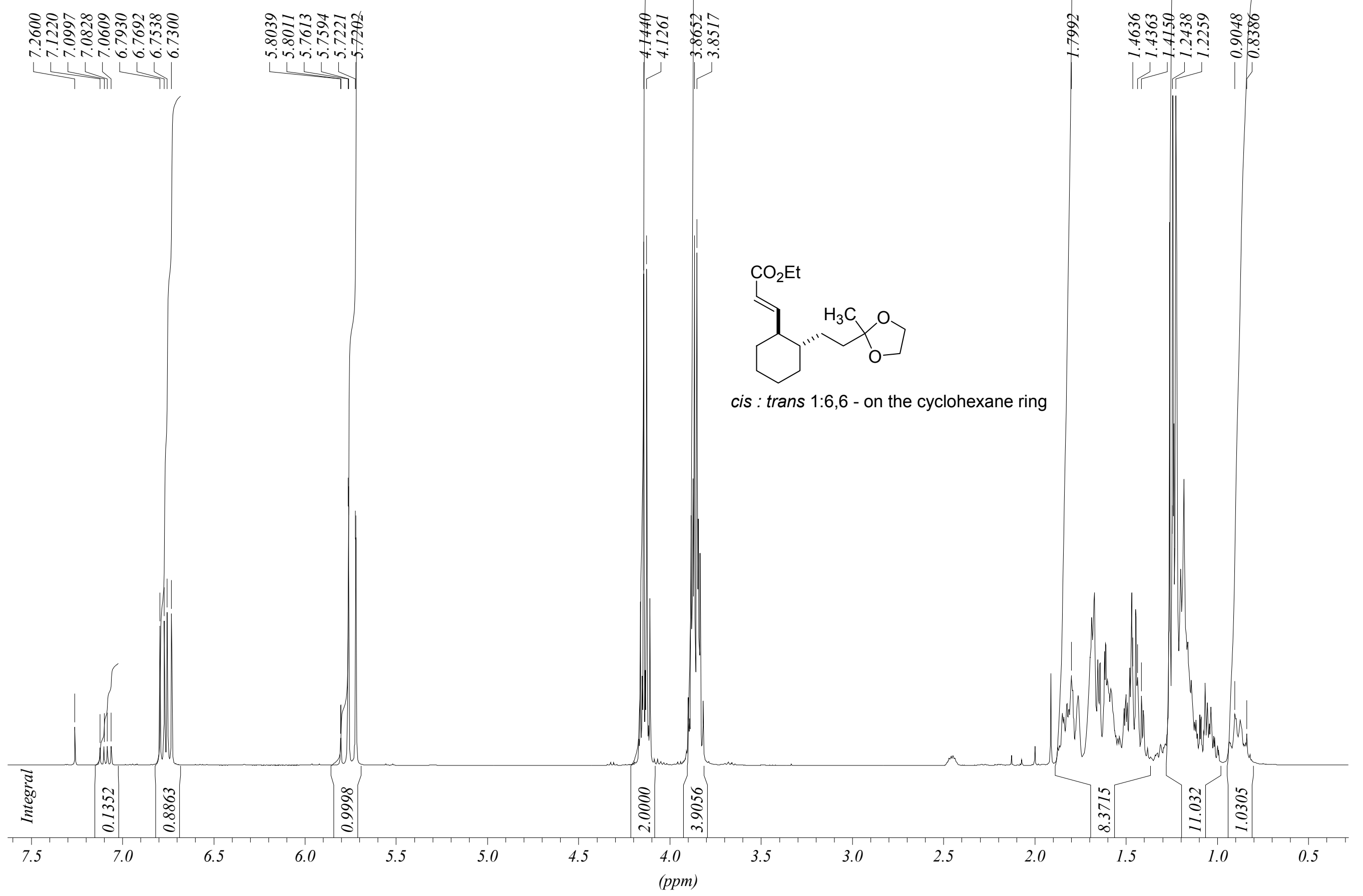




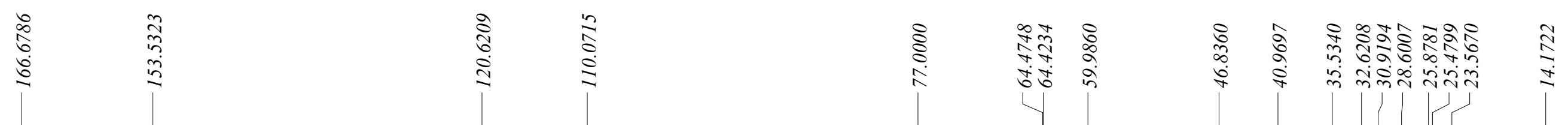

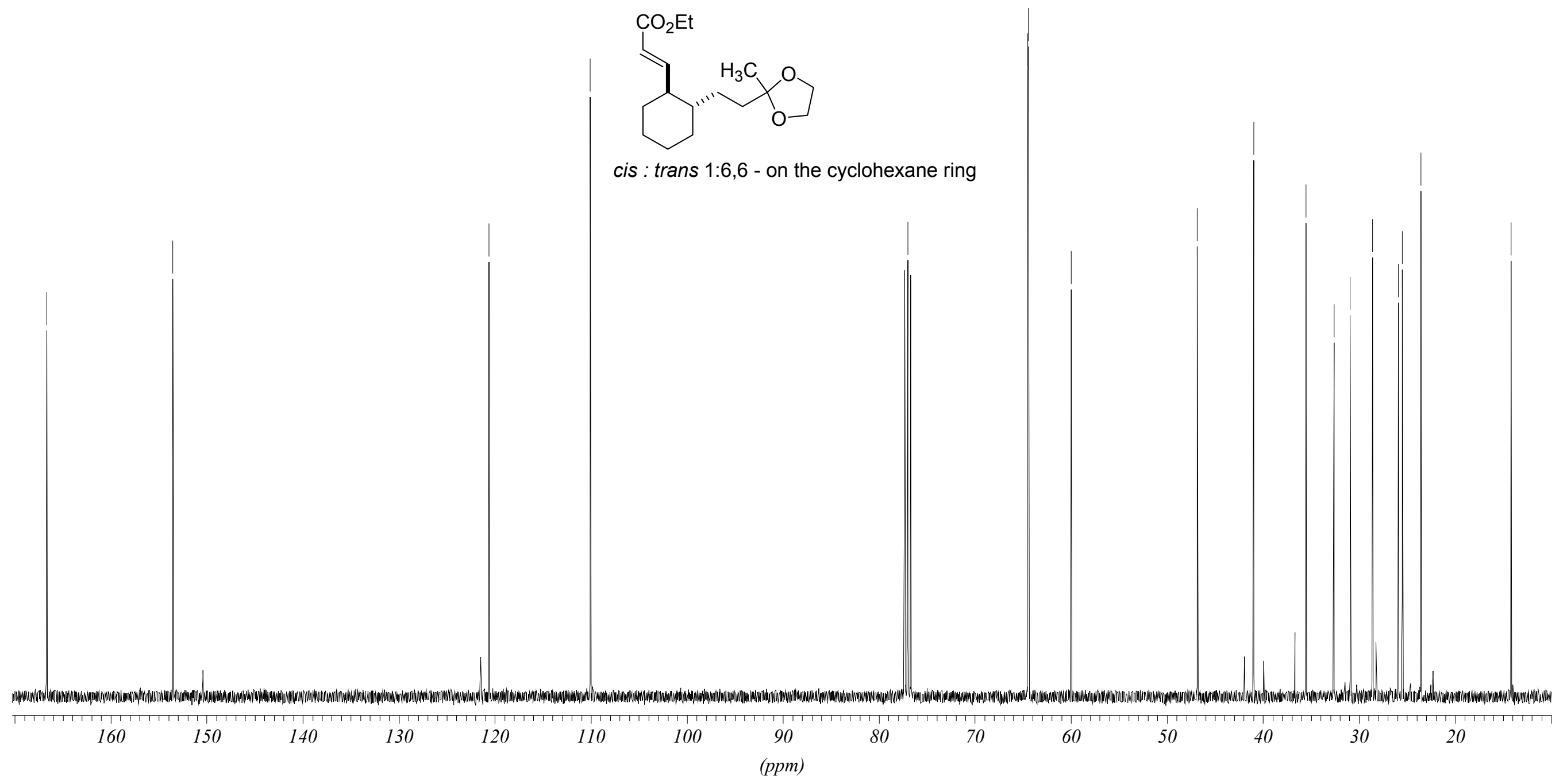




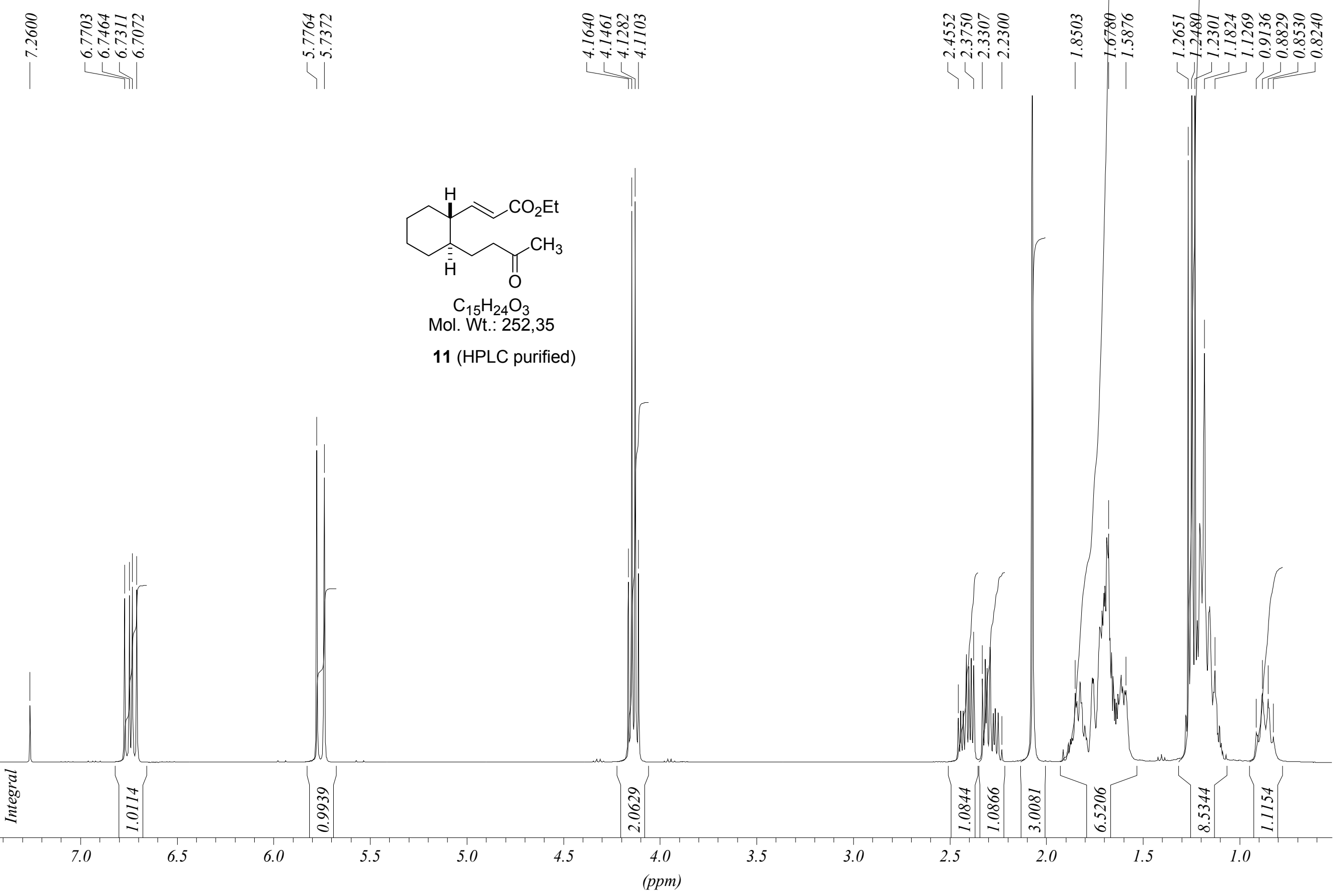



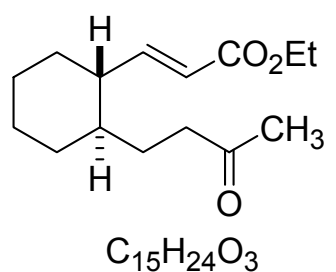

Mol. Wt.: 252,35

11 (HPLC purified)

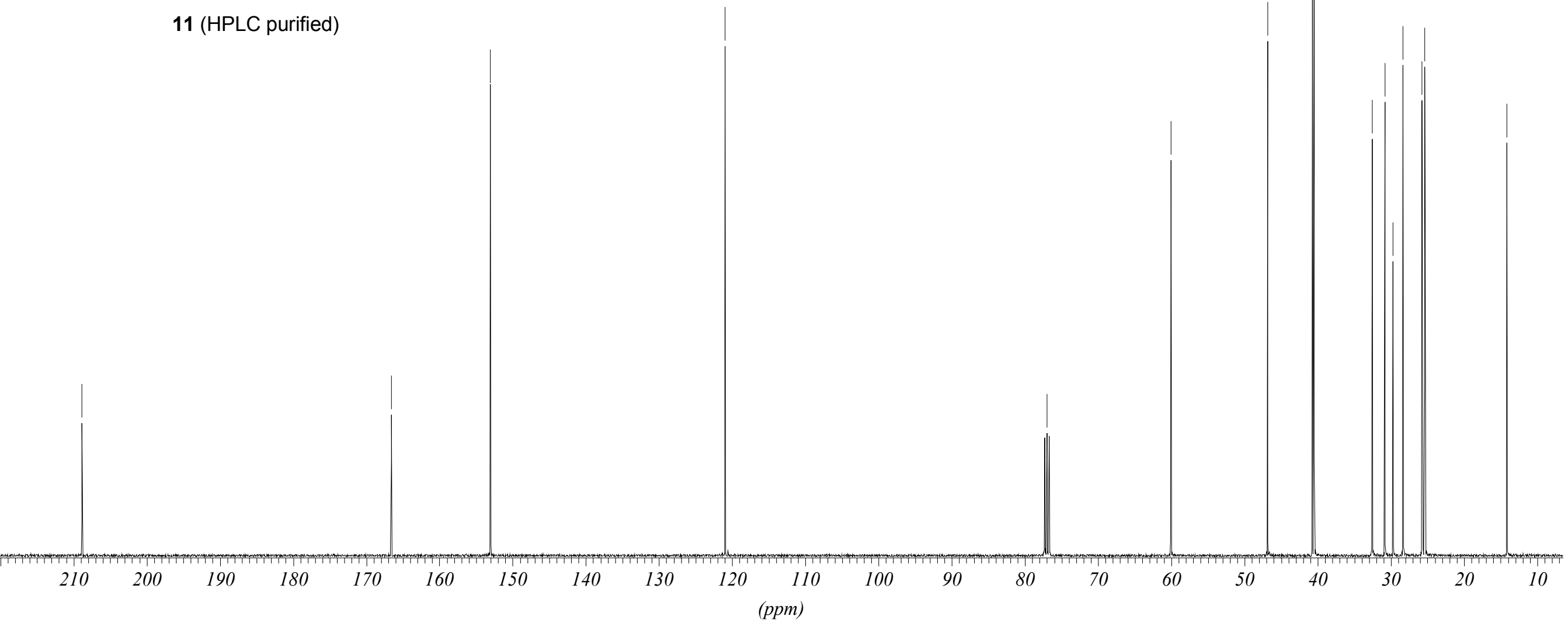


in $\mathrm{C}_{6} \mathrm{D}_{6}, 500 \mathrm{Mhz}$

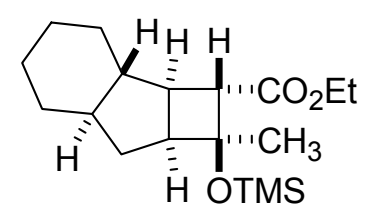

12a (kinetic)

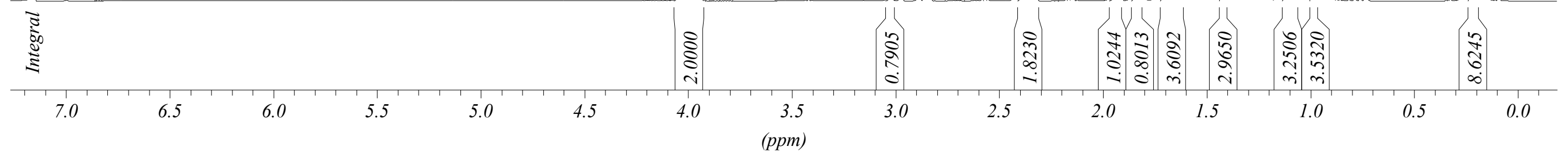




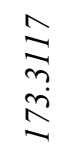

in $\mathrm{C}_{6} \mathrm{D}_{6}, 13 \mathrm{C} \mathrm{BB}, 400 \mathrm{Mhz}$

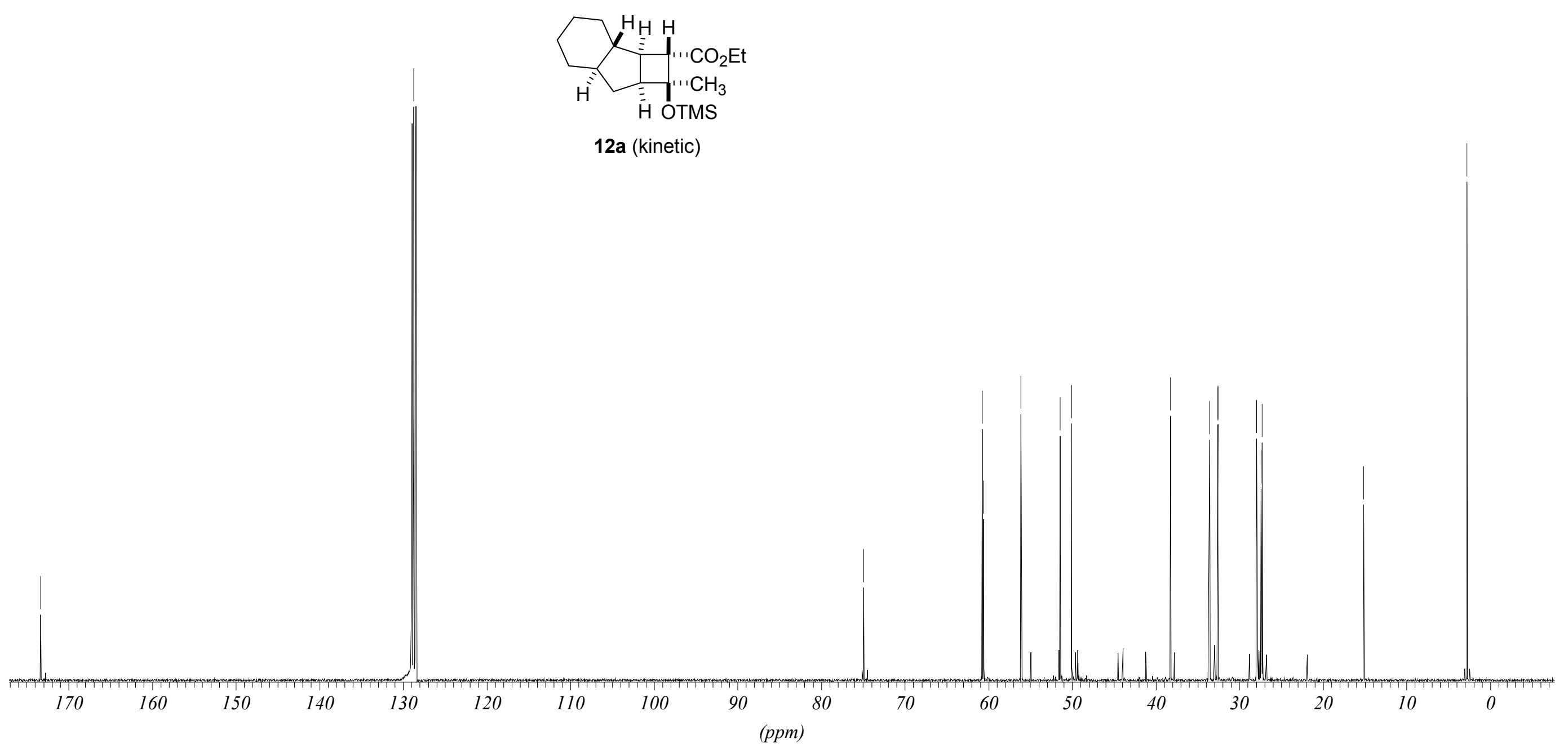




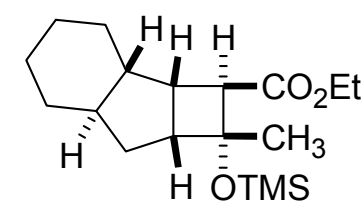

12b (thermodynamic)

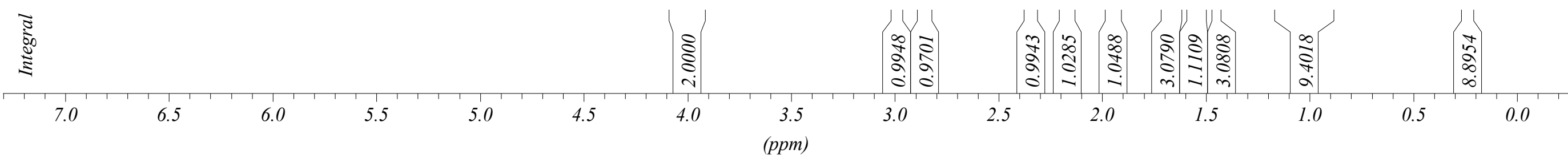



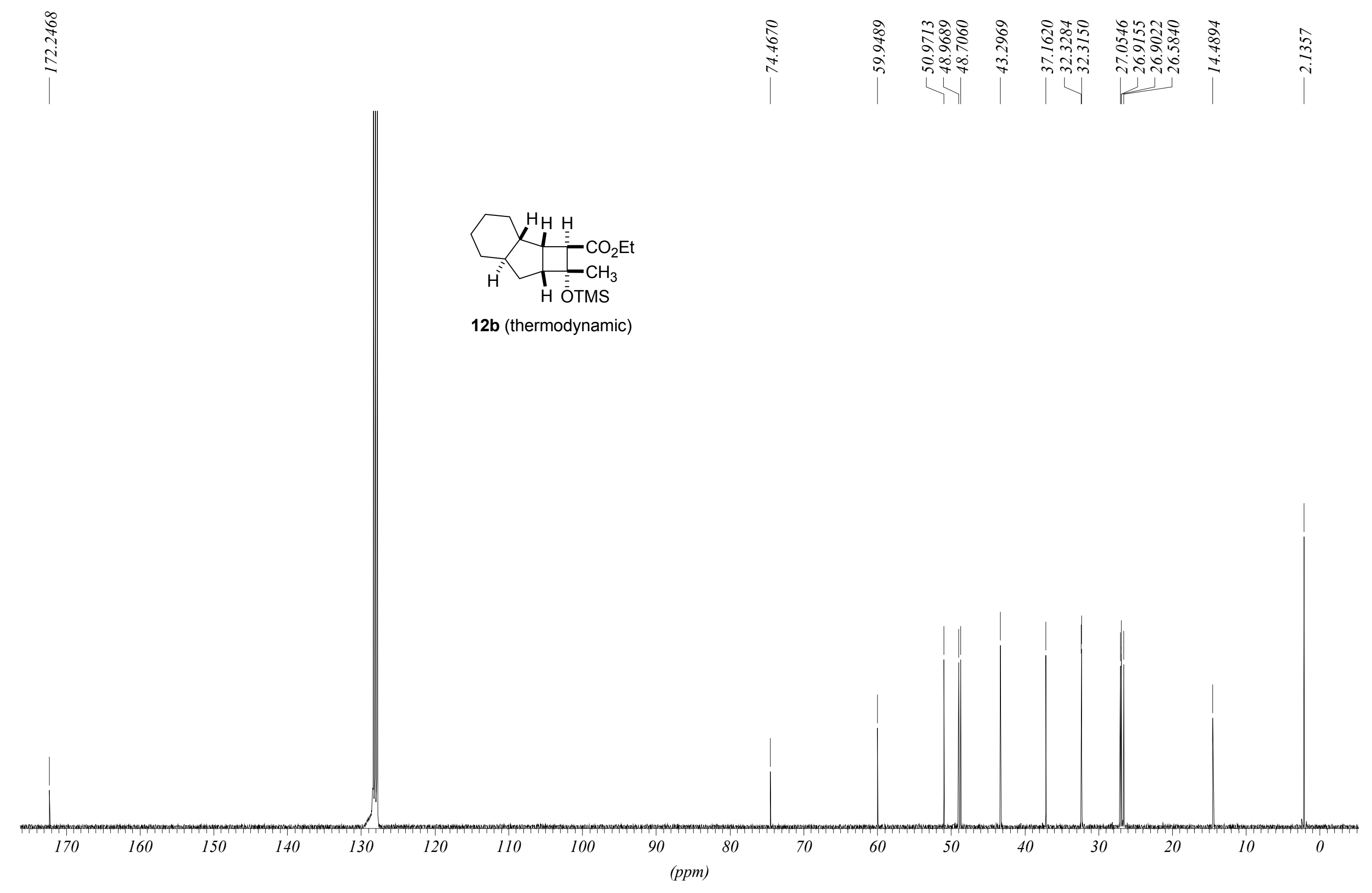
NOE irrad. at $1,66 \mathrm{ppm}$ in $\mathrm{C}_{6} \mathrm{D}_{6}$

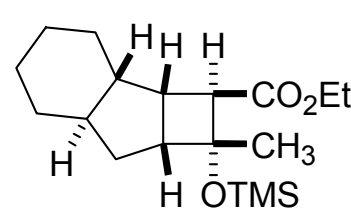

12b (thermodynamic)

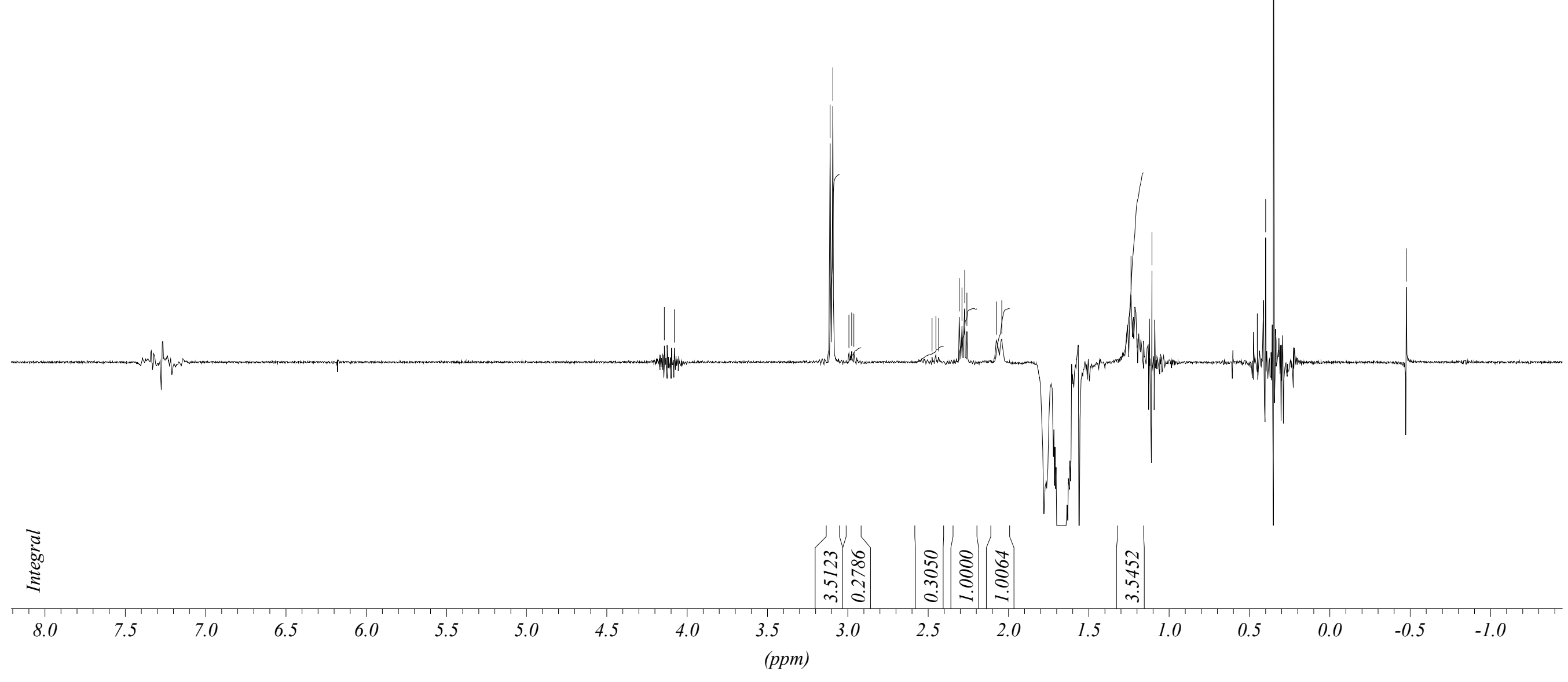


NOE irrad. at $2,46 \mathrm{ppm}$ in $\mathrm{C}_{6} \mathrm{D}_{6}$

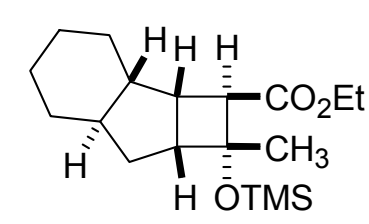

12b (thermodynamic)

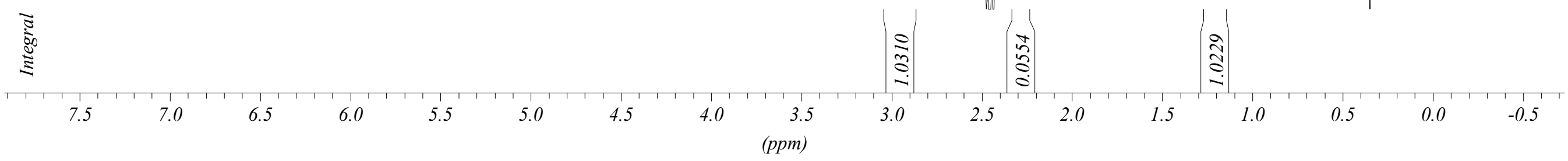




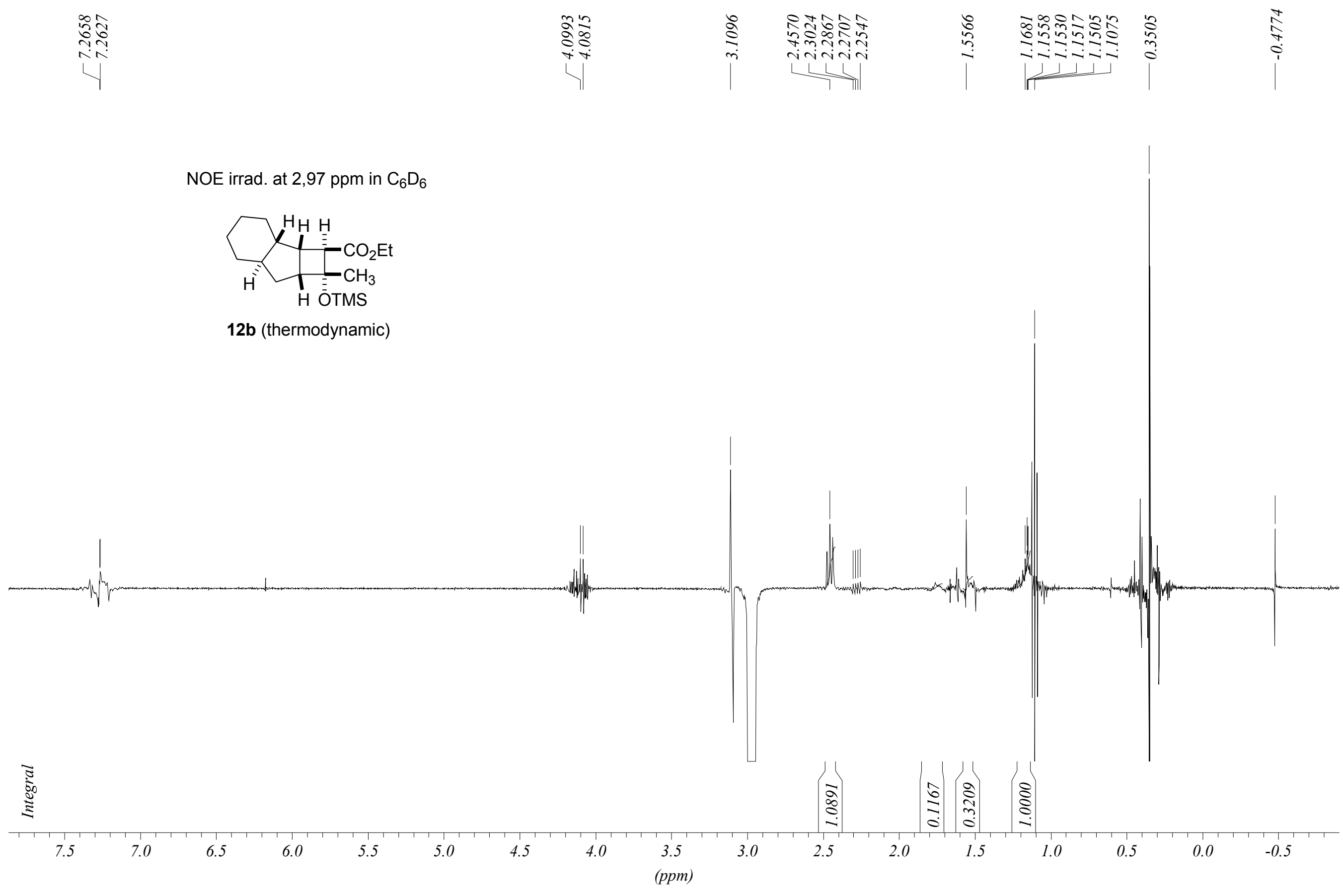


NOE irrad. at $3,10 \mathrm{ppm}$ in $\mathrm{C}_{6} \mathrm{D}_{6}$

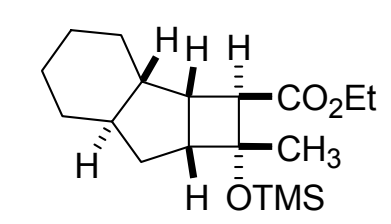

12b (thermodynamic)

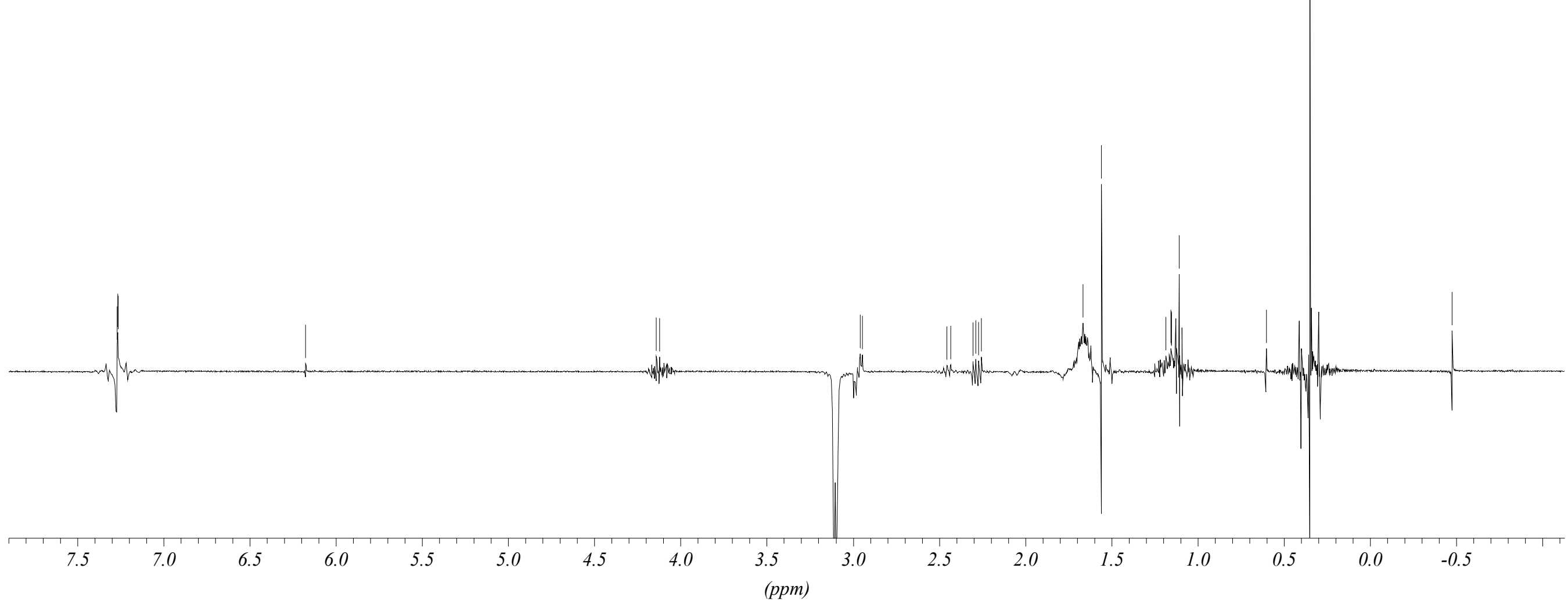


$\mathrm{CH}_{3}$ at $1.96 \mathrm{ppm}$ in $\mathrm{C}_{6} \mathrm{D}_{6}$

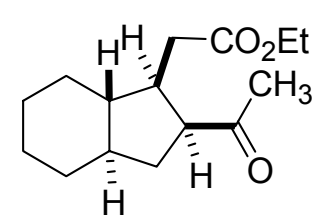

$\mathrm{C}_{15} \mathrm{H}_{24} \mathrm{O}_{3}$

Mol. Wt.: 252,35

$13 a$

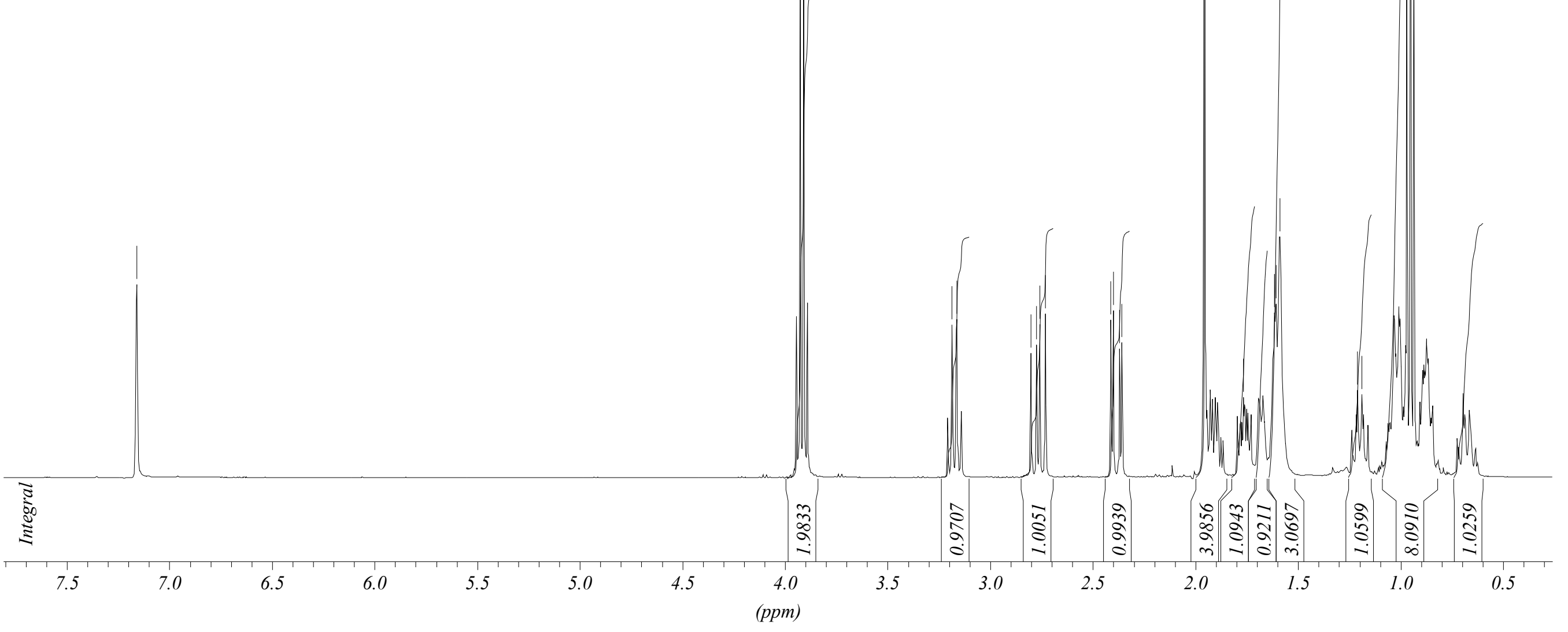



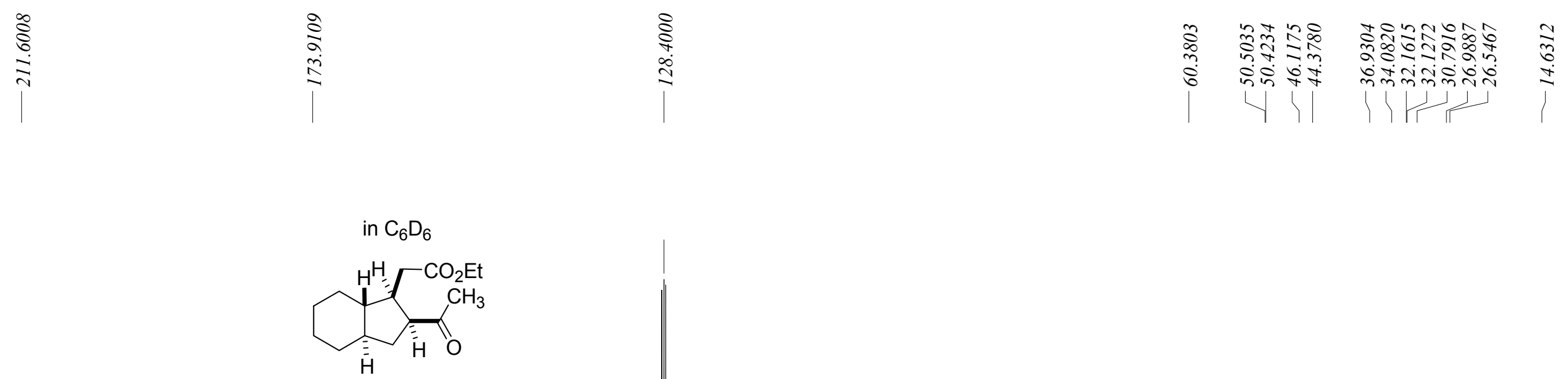

$\mathrm{C}_{15} \mathrm{H}_{24} \mathrm{O}_{3}$

Mol. Wt.: 252,35

$13 a$ 


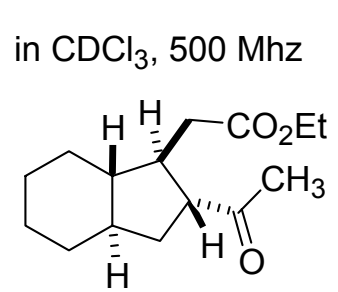

$14 a$

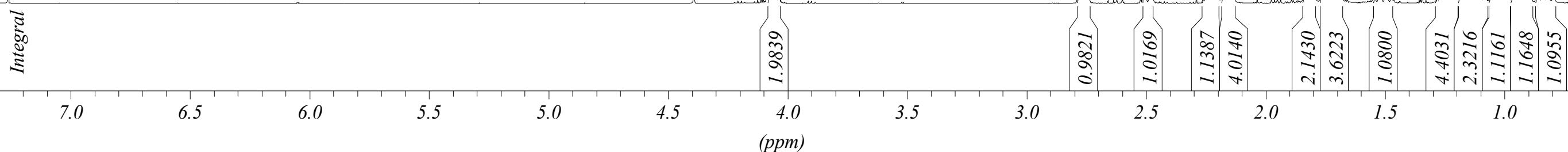




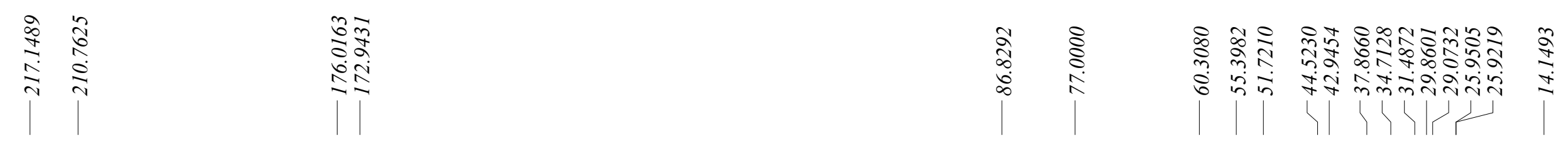

\section{in $\mathrm{CDCl}_{3}, 400 \mathrm{Mhz}, 13 \mathrm{C} \mathrm{BB}$}

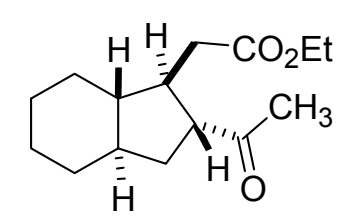

$14 a$

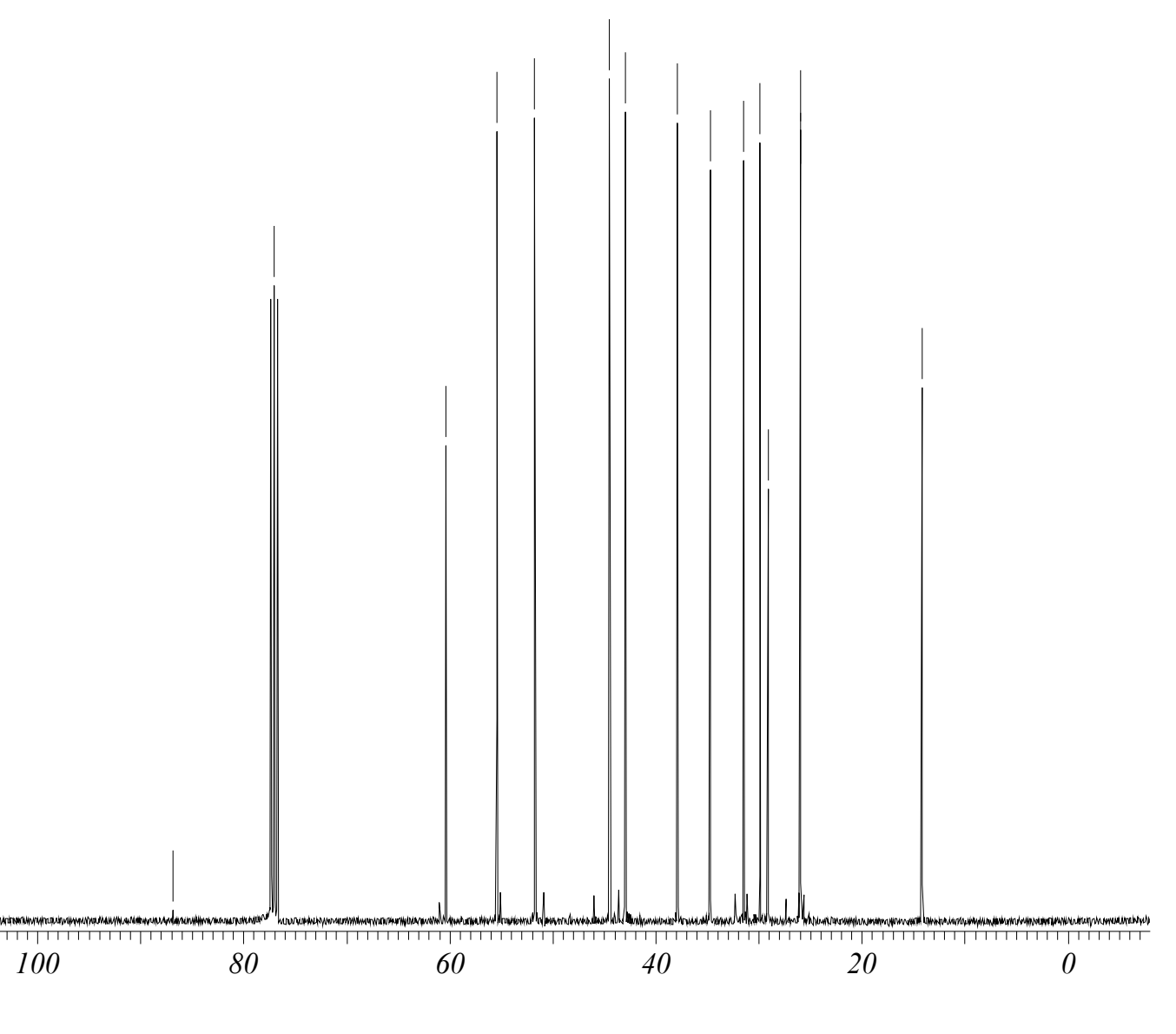




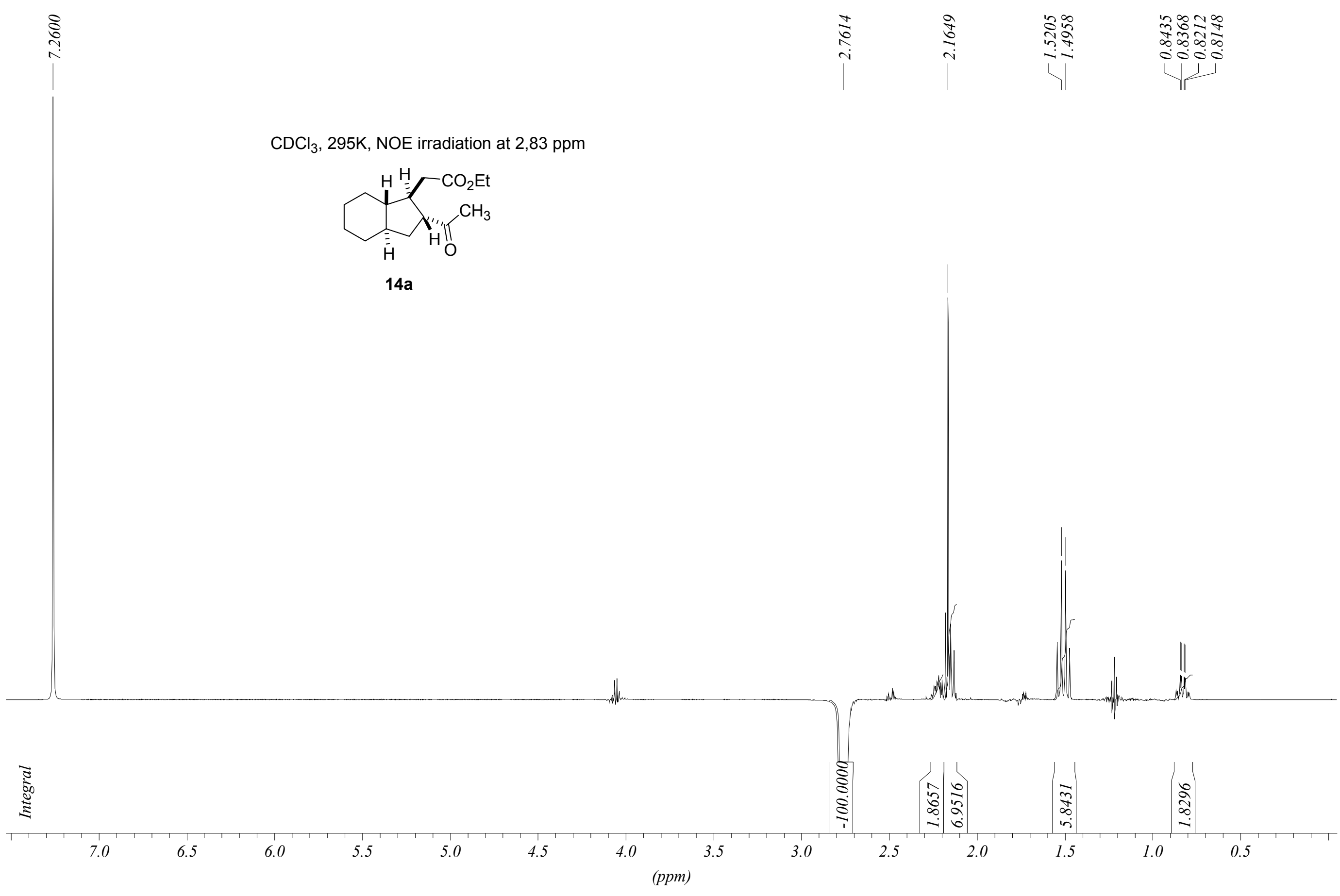


$\mathrm{CDCl}_{3}, 295 \mathrm{~K}, \mathrm{NOE}$ irradiation at 2,56 ppm<smiles>CCOC[C@H]1C(C(C)=O)CC2CCCC[C@@H]2[C@H]1C(C)=O</smiles>

$14 a$

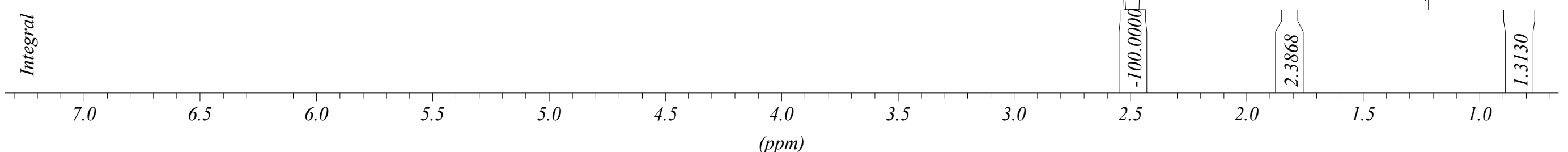


$\mathrm{CH}_{3}$ at $1.91 \mathrm{ppm}$ in $\mathrm{C}_{6} \mathrm{D}_{6} \quad \mathrm{CH}_{3}$ at $1.93 \mathrm{ppm}$ in $\mathrm{C}_{6} \mathrm{D}_{6}$

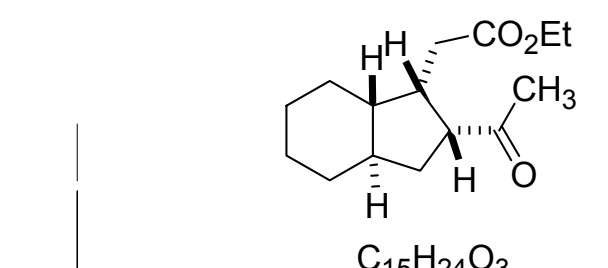
Mol. Wt.: 252,35

$\mathrm{C}_{15} \mathrm{H}_{24} \mathrm{O}_{3}$

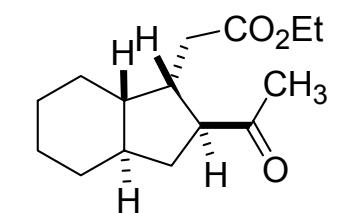

$\mathrm{C}_{15} \mathrm{H}_{24} \mathrm{O}_{3}$ Mol. Wt.: 252,35

13b

$14 b$

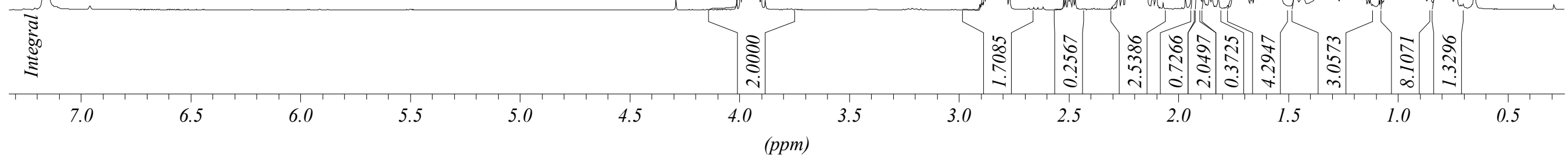


$\mathrm{CH}_{3}$ at 1.93 ppm in $\mathrm{C}_{6} \mathrm{D}_{6}$

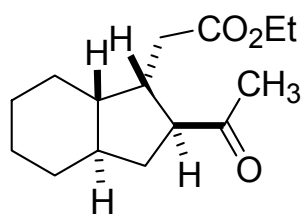

$\mathrm{C}_{15} \mathrm{H}_{24} \mathrm{O}_{3}$

Mol. Wt.: 252,35

$14 b$

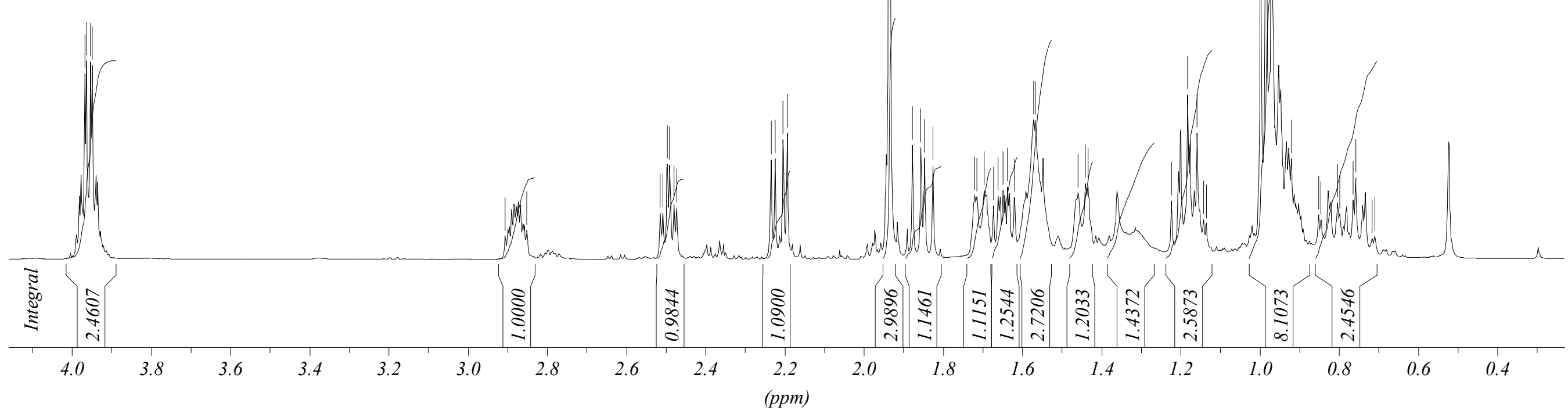




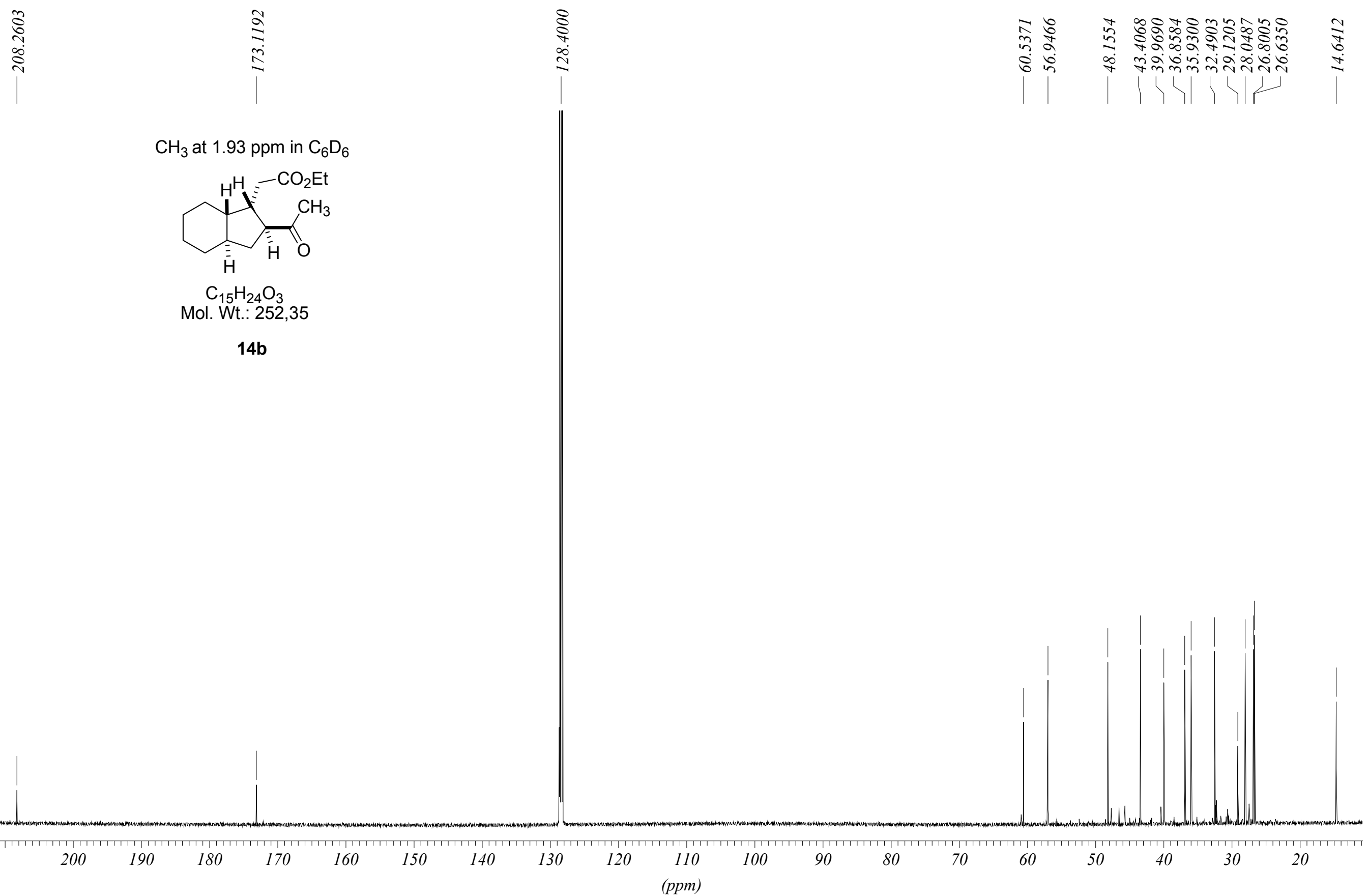




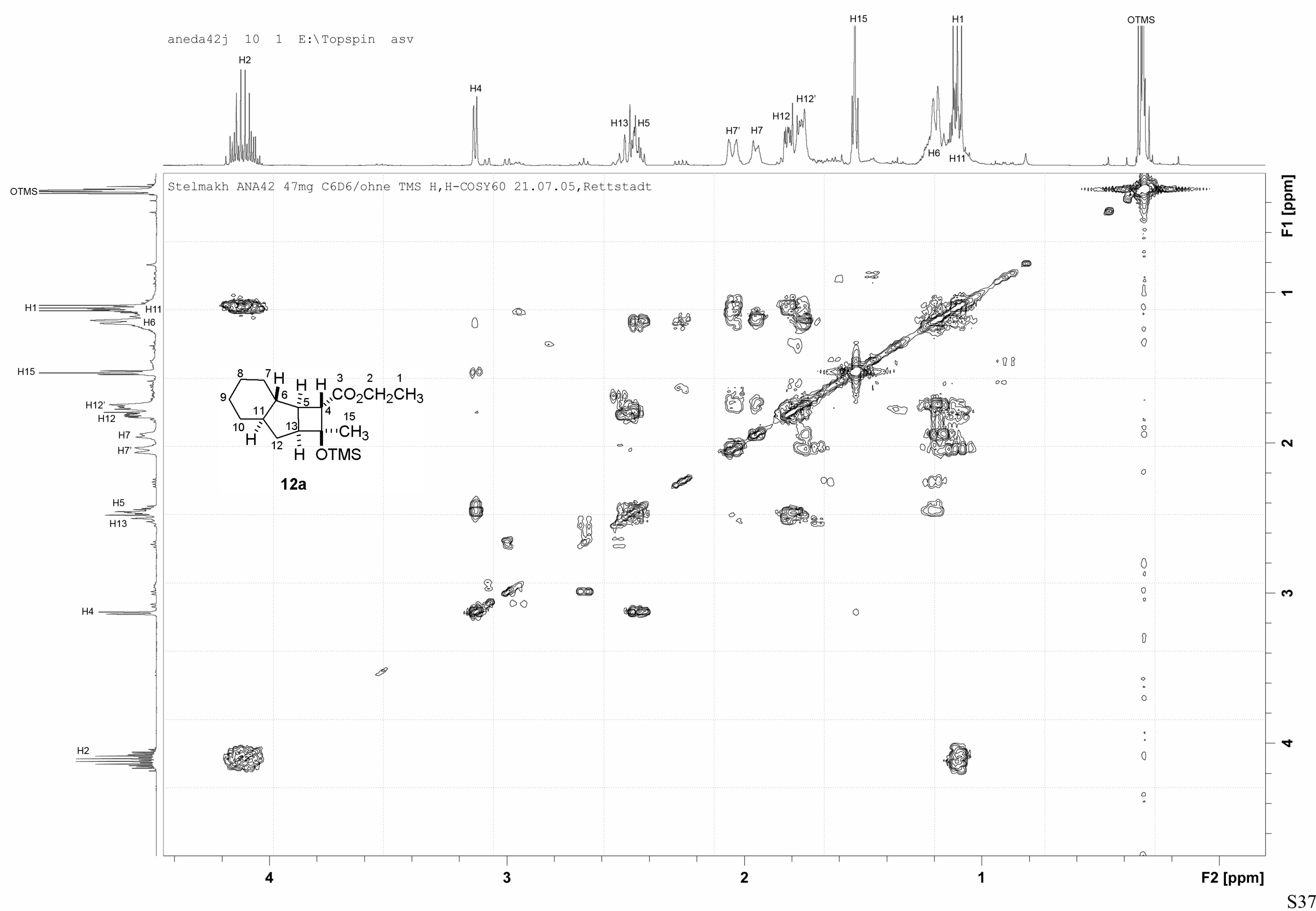


anmba42j $10 \quad 1 \quad$ E: \Topspin asv

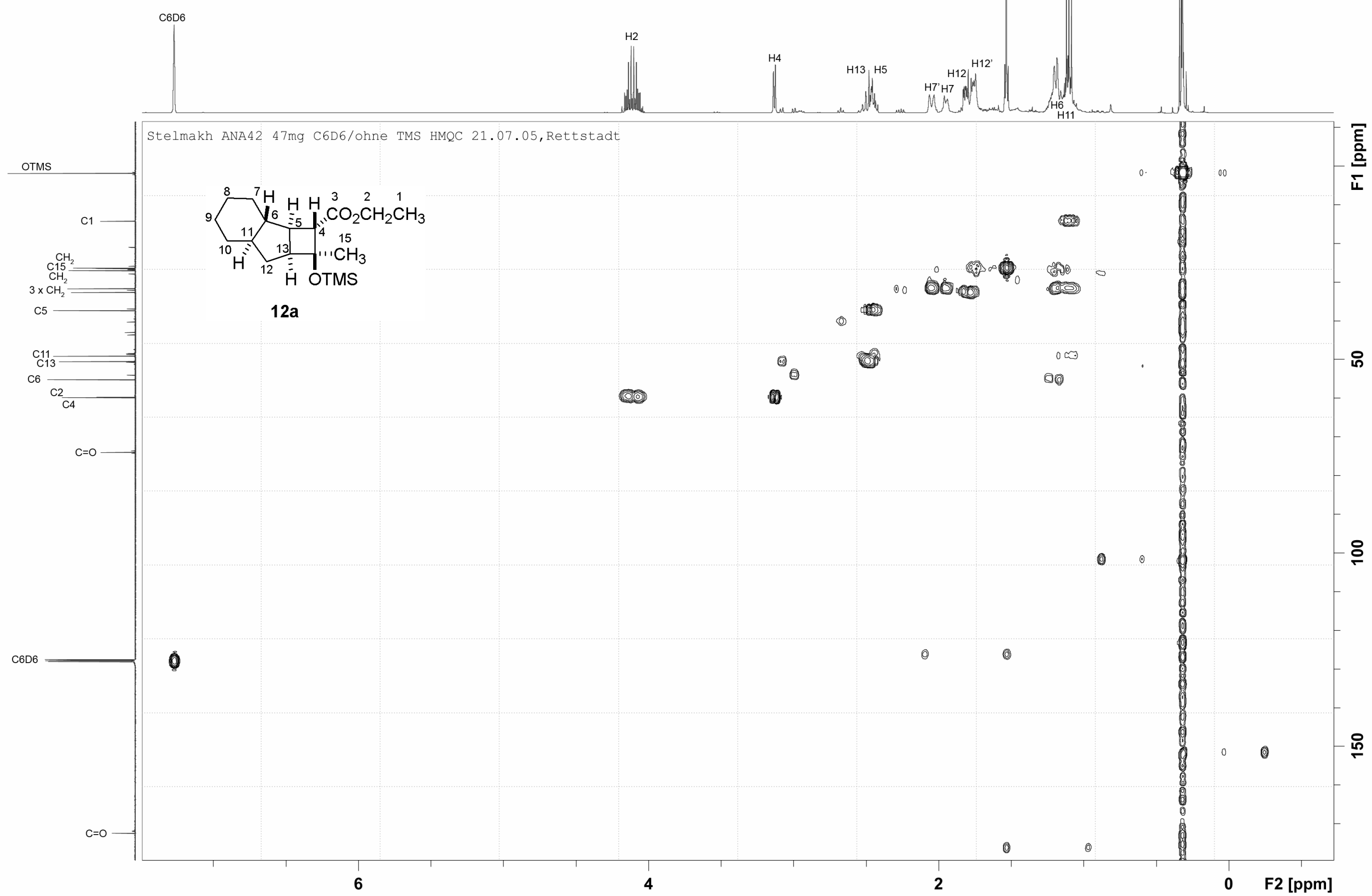

S38 


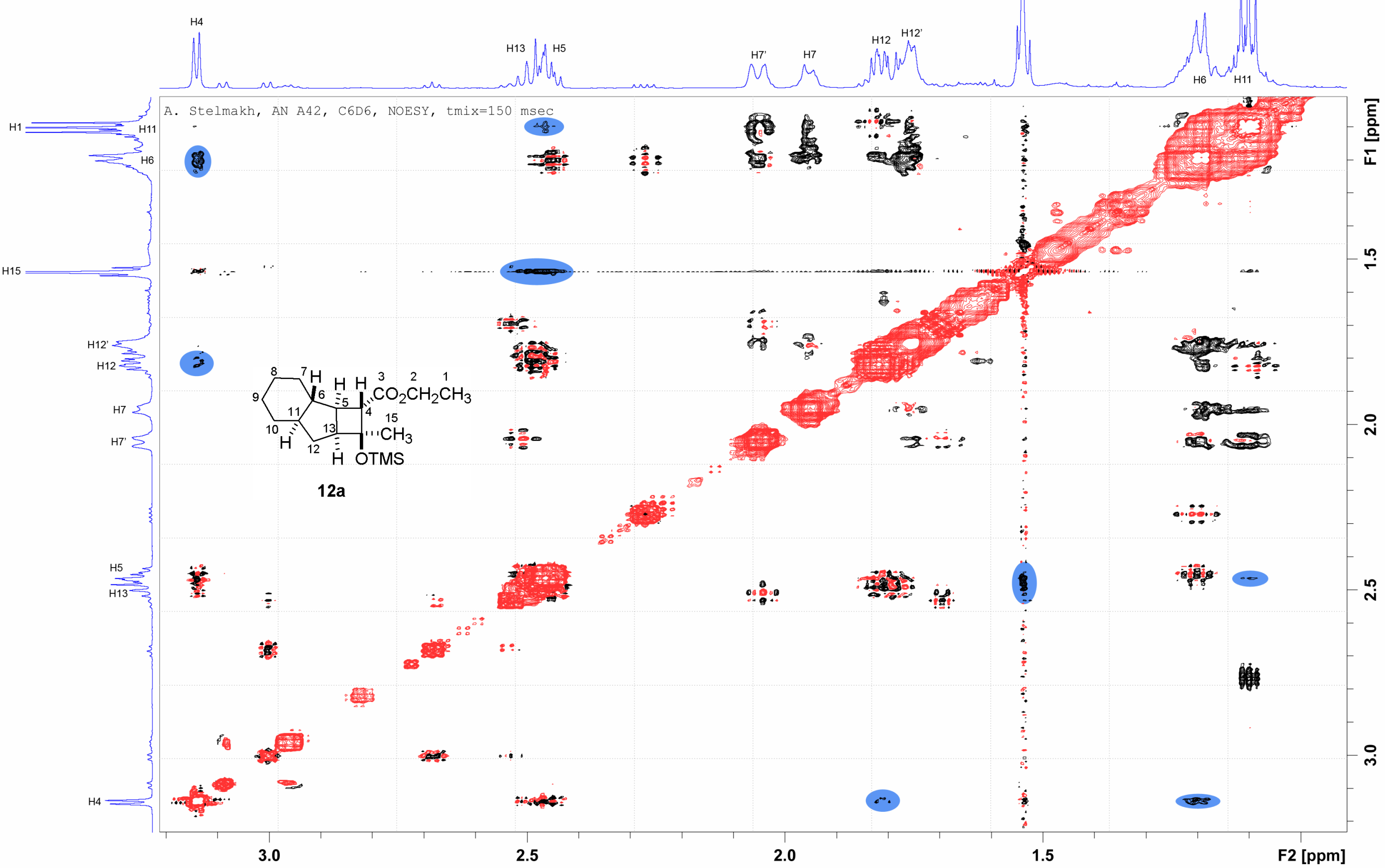




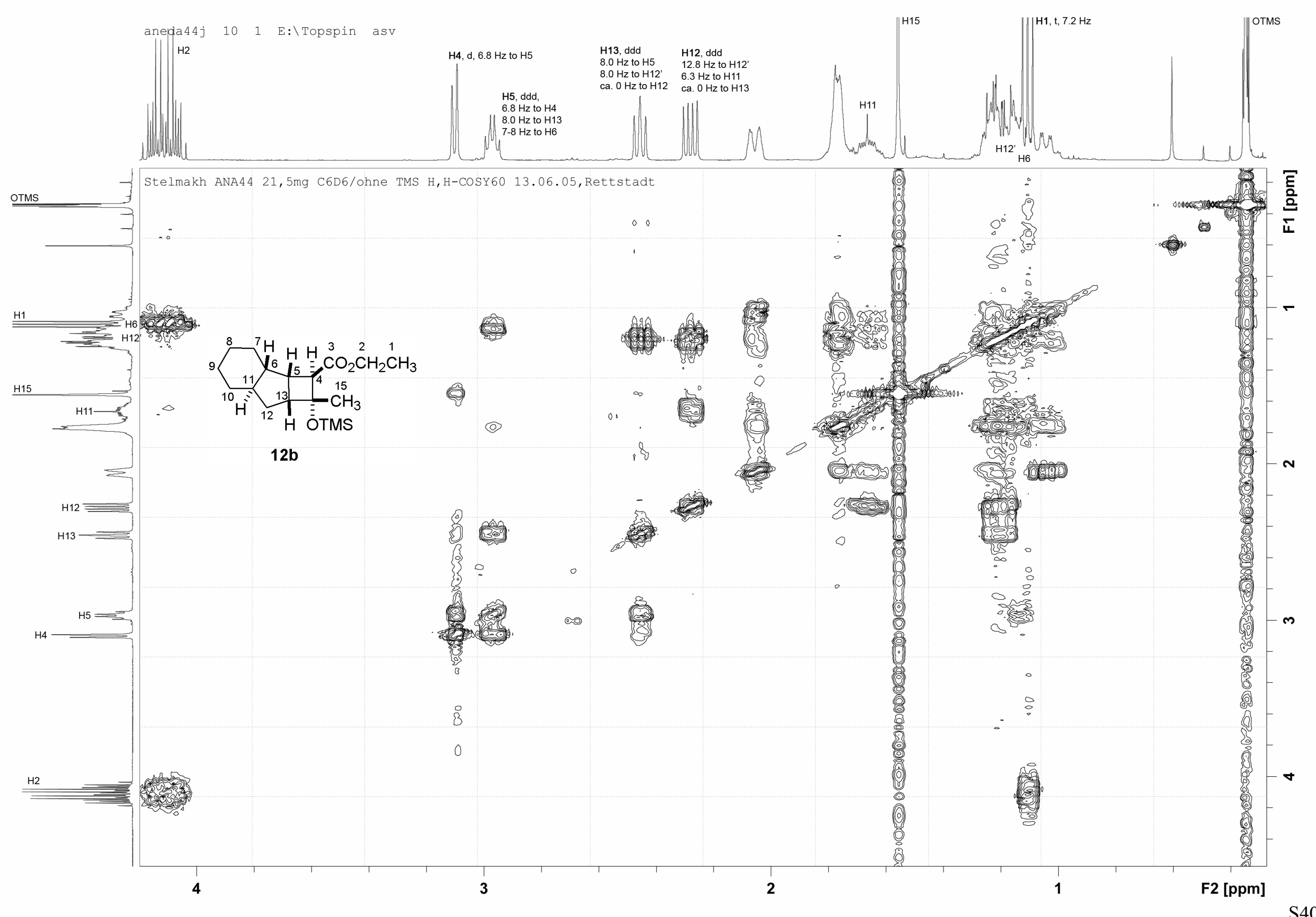




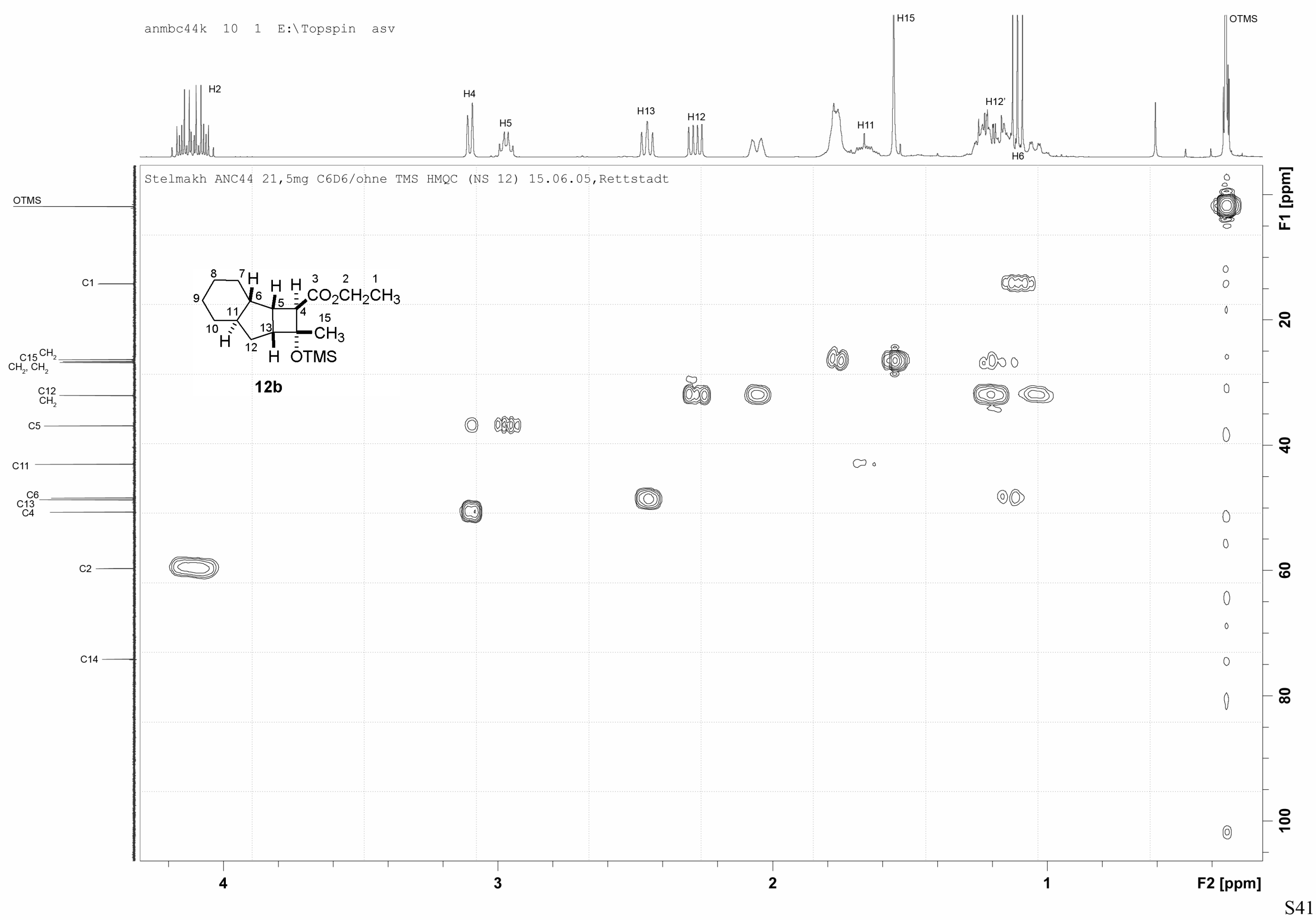




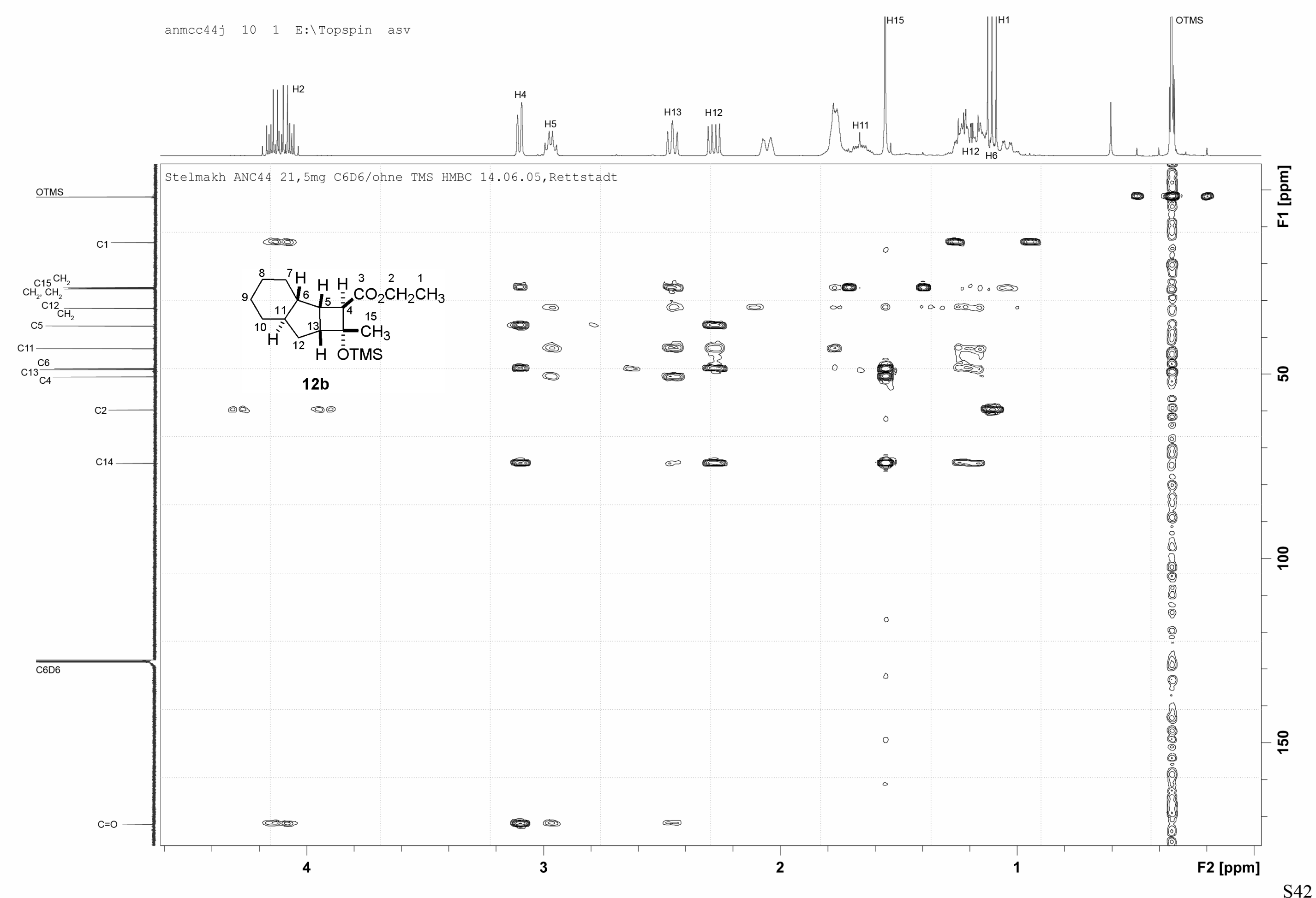




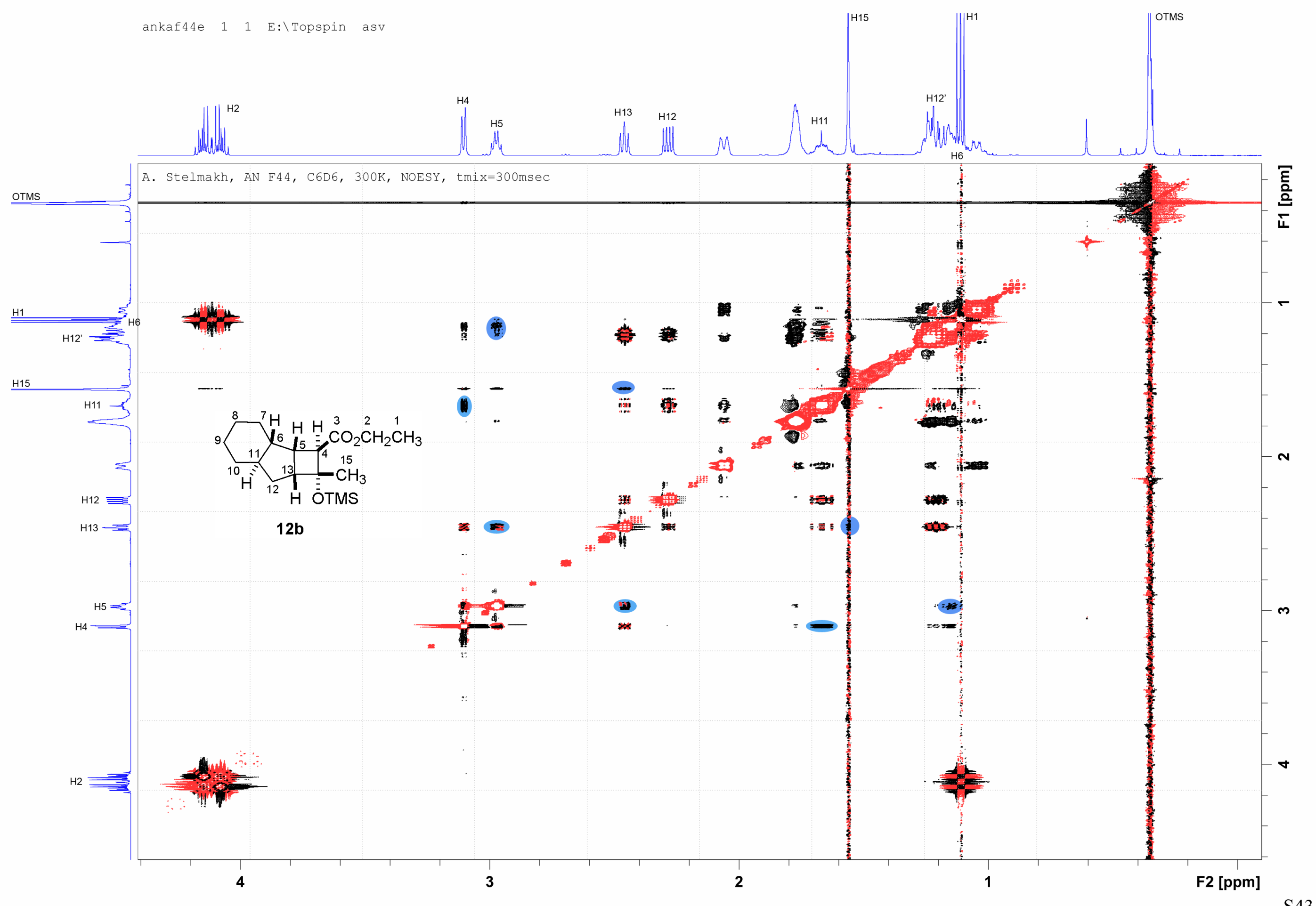




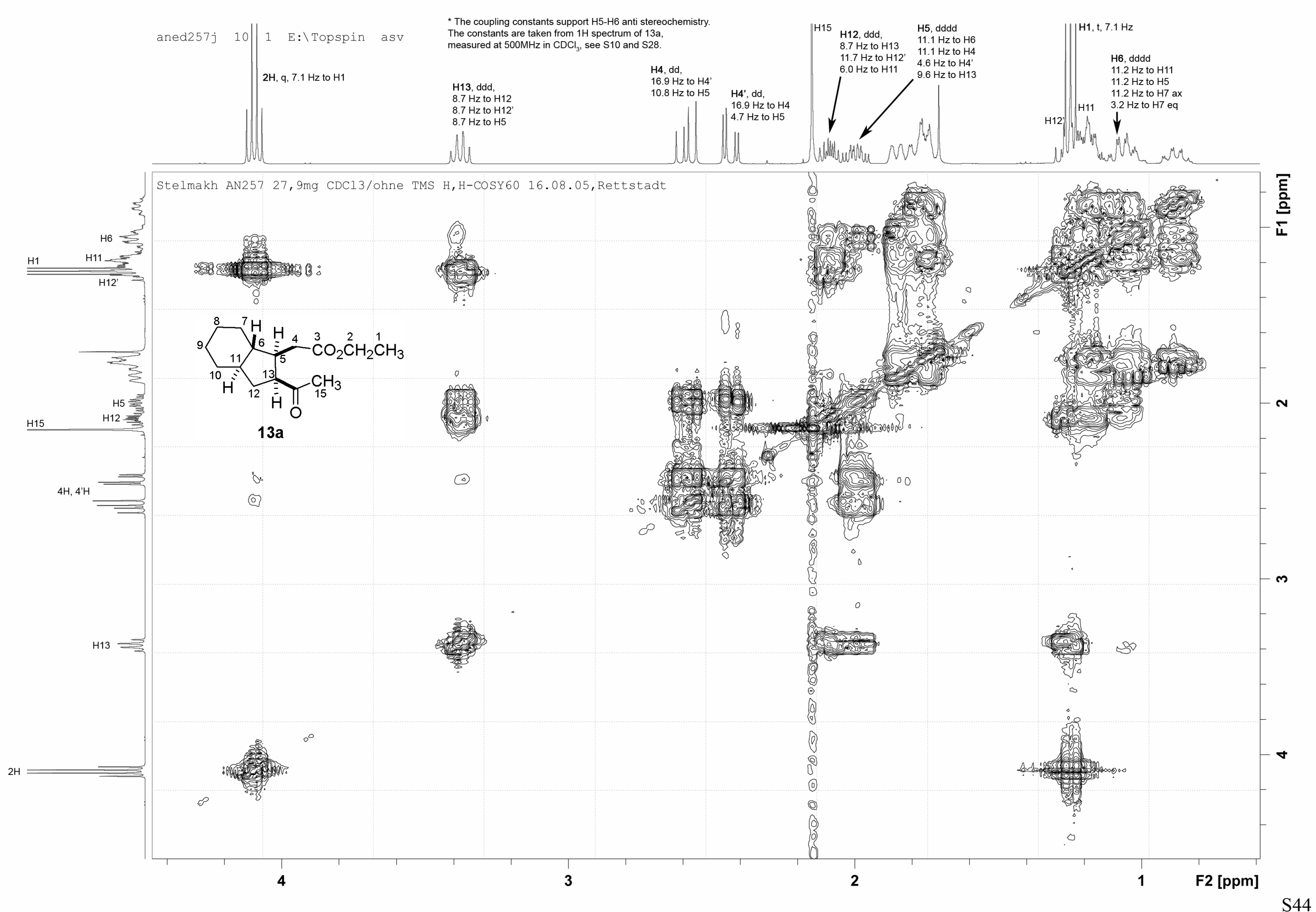




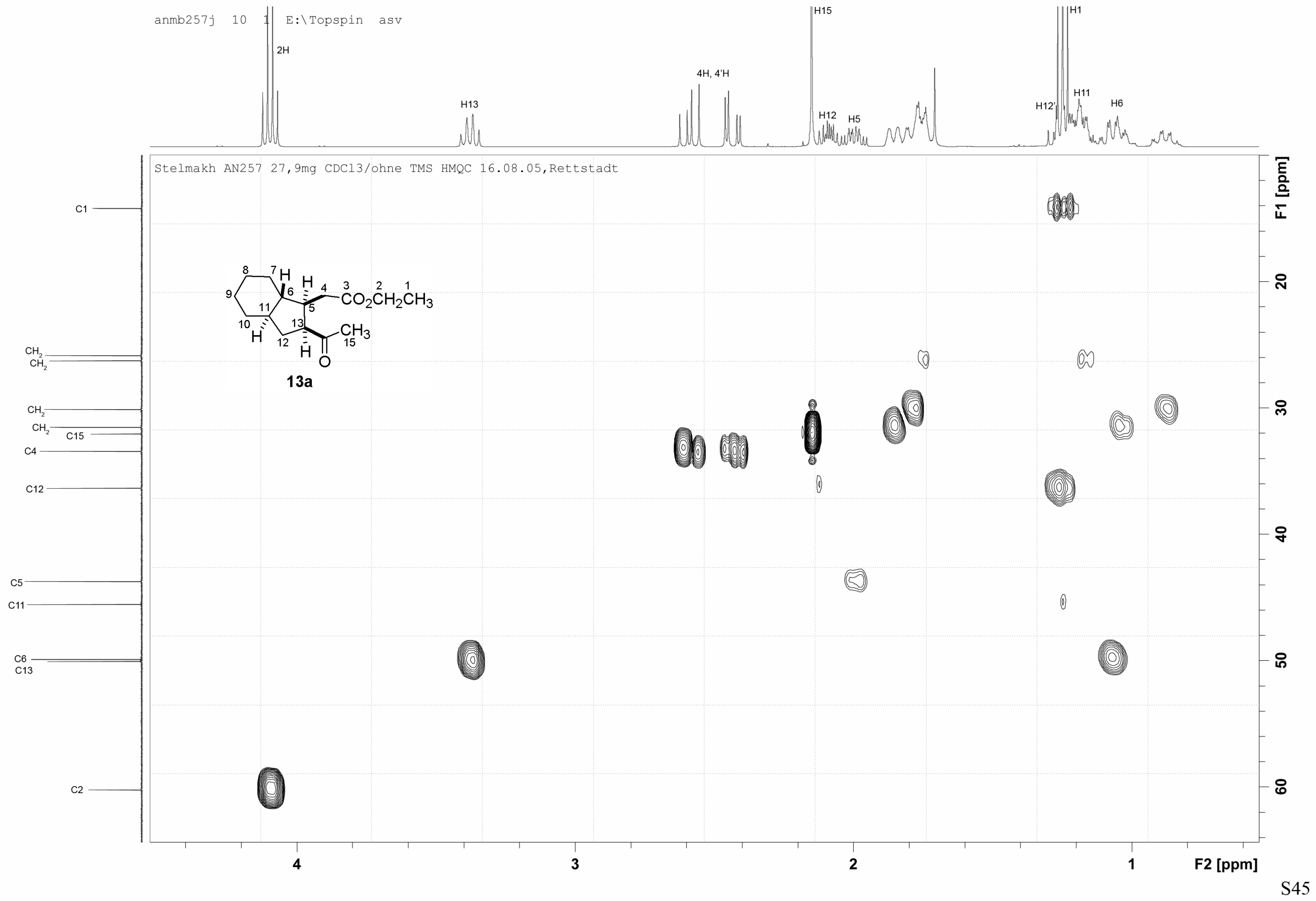




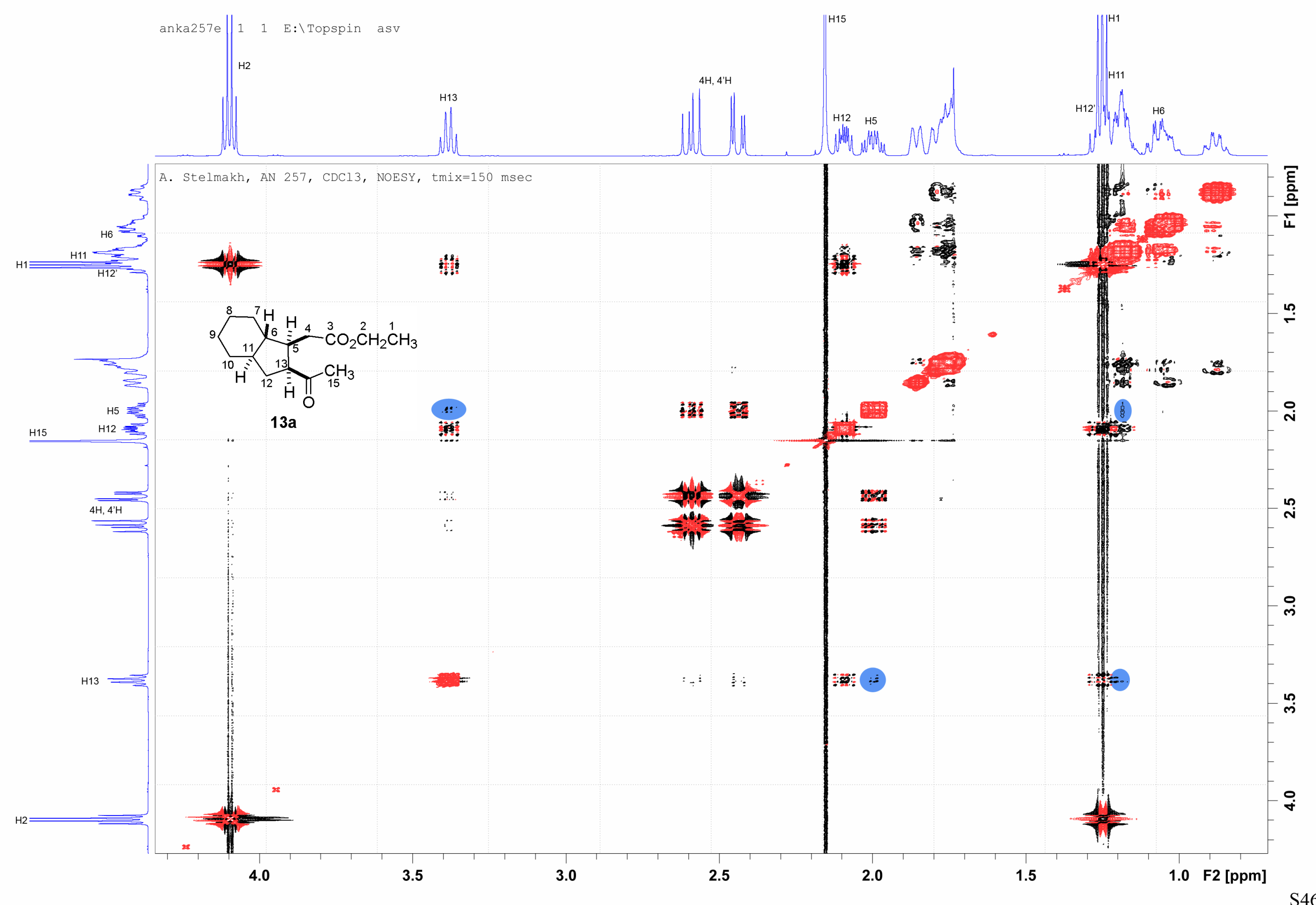




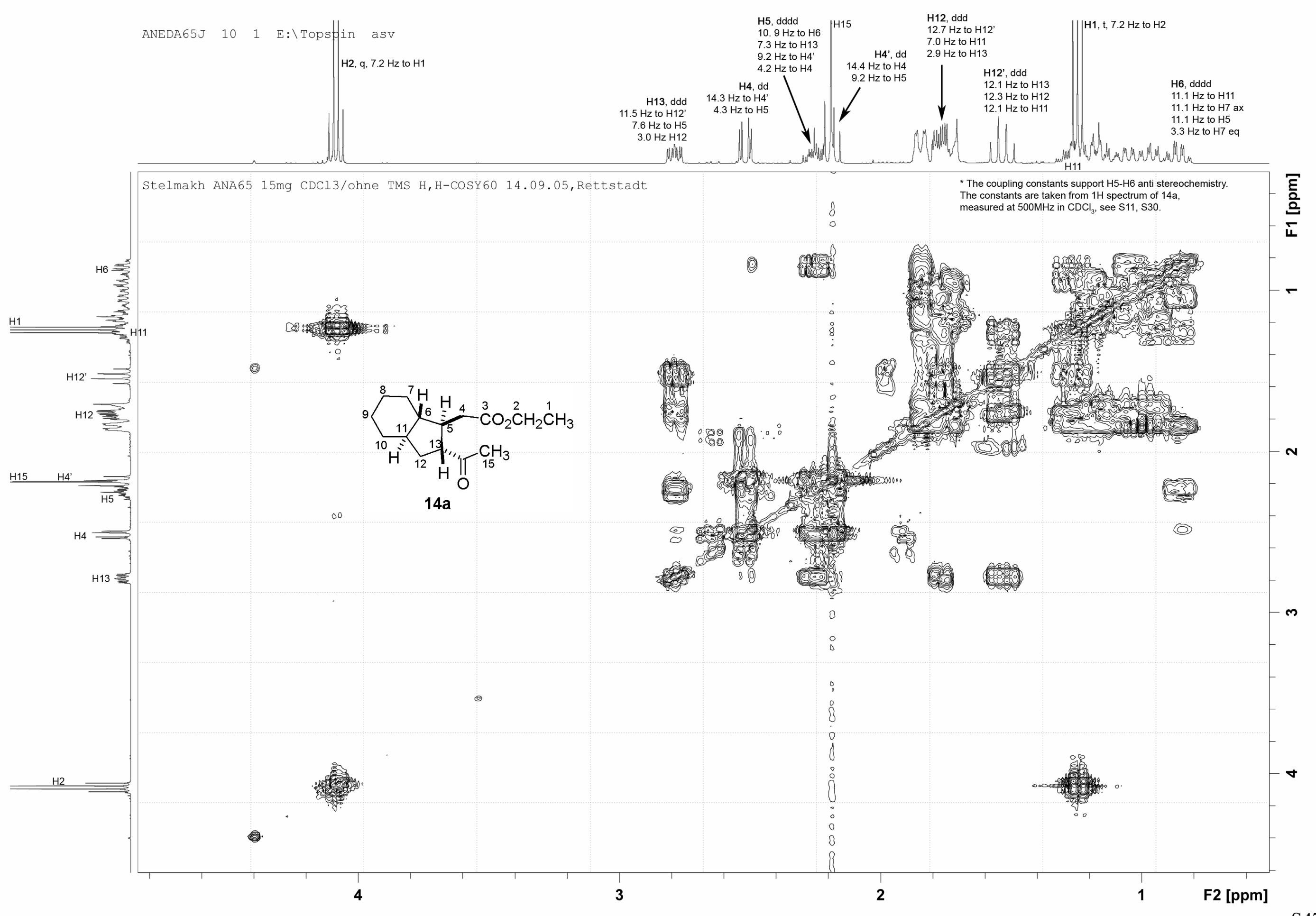




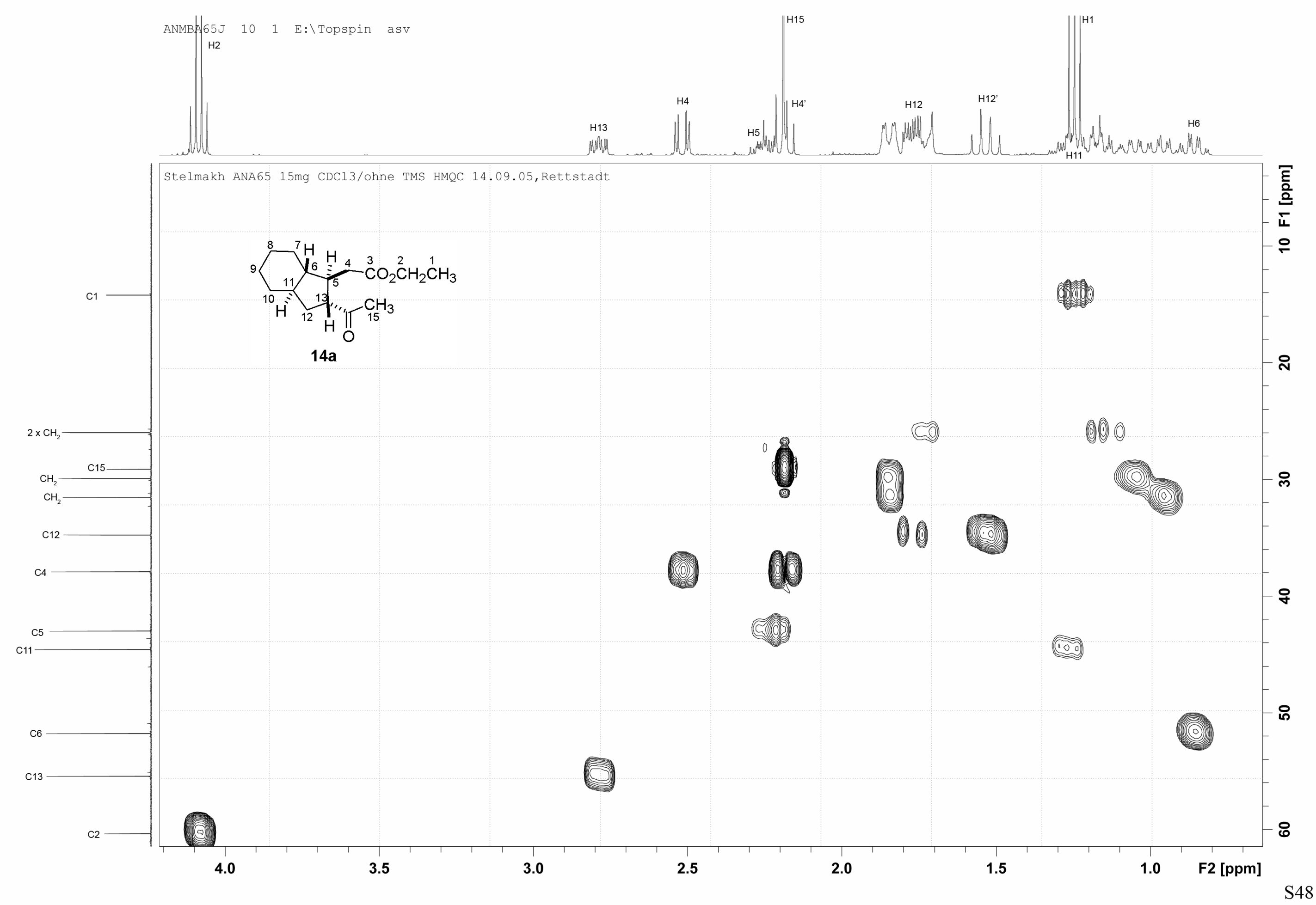




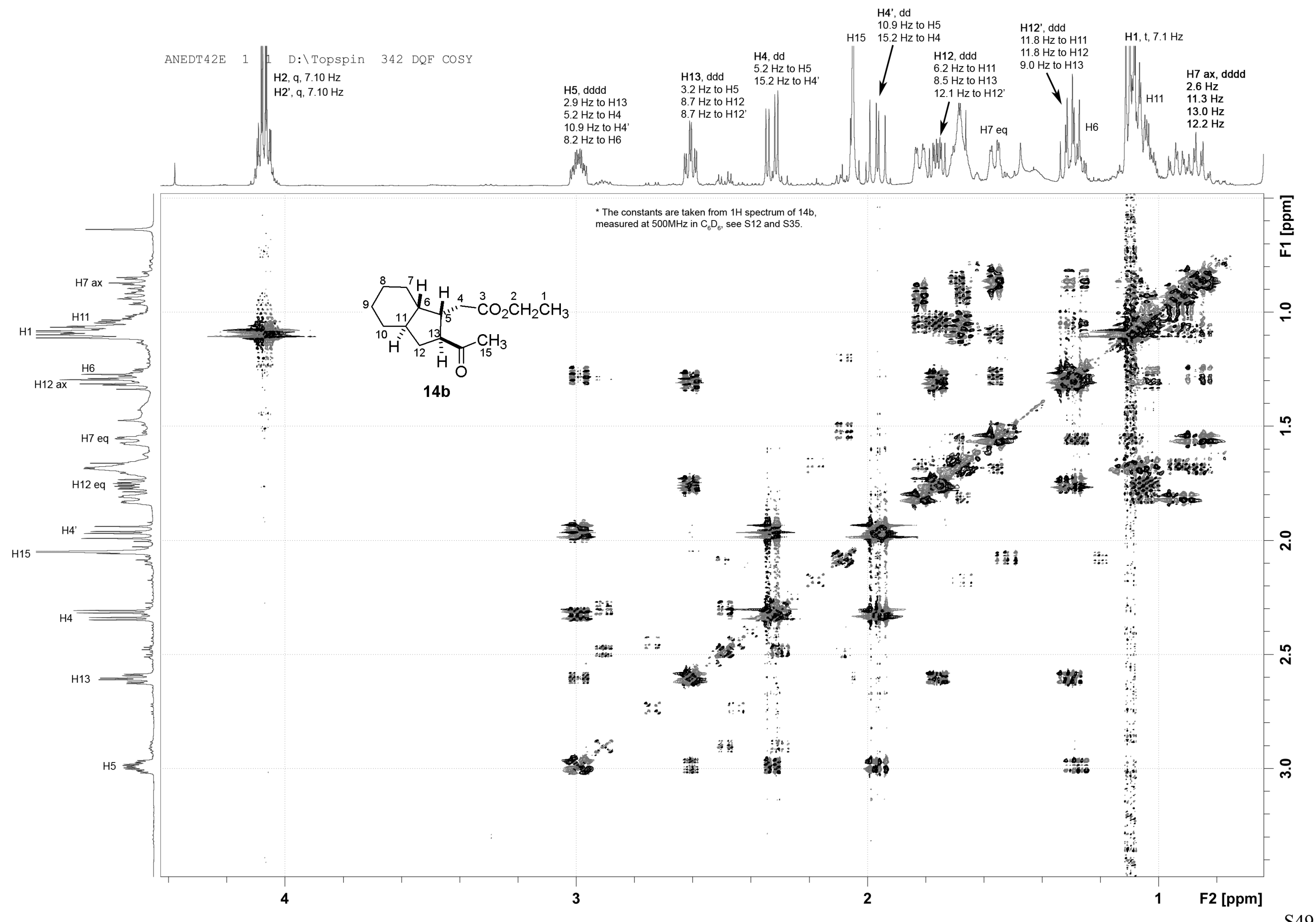




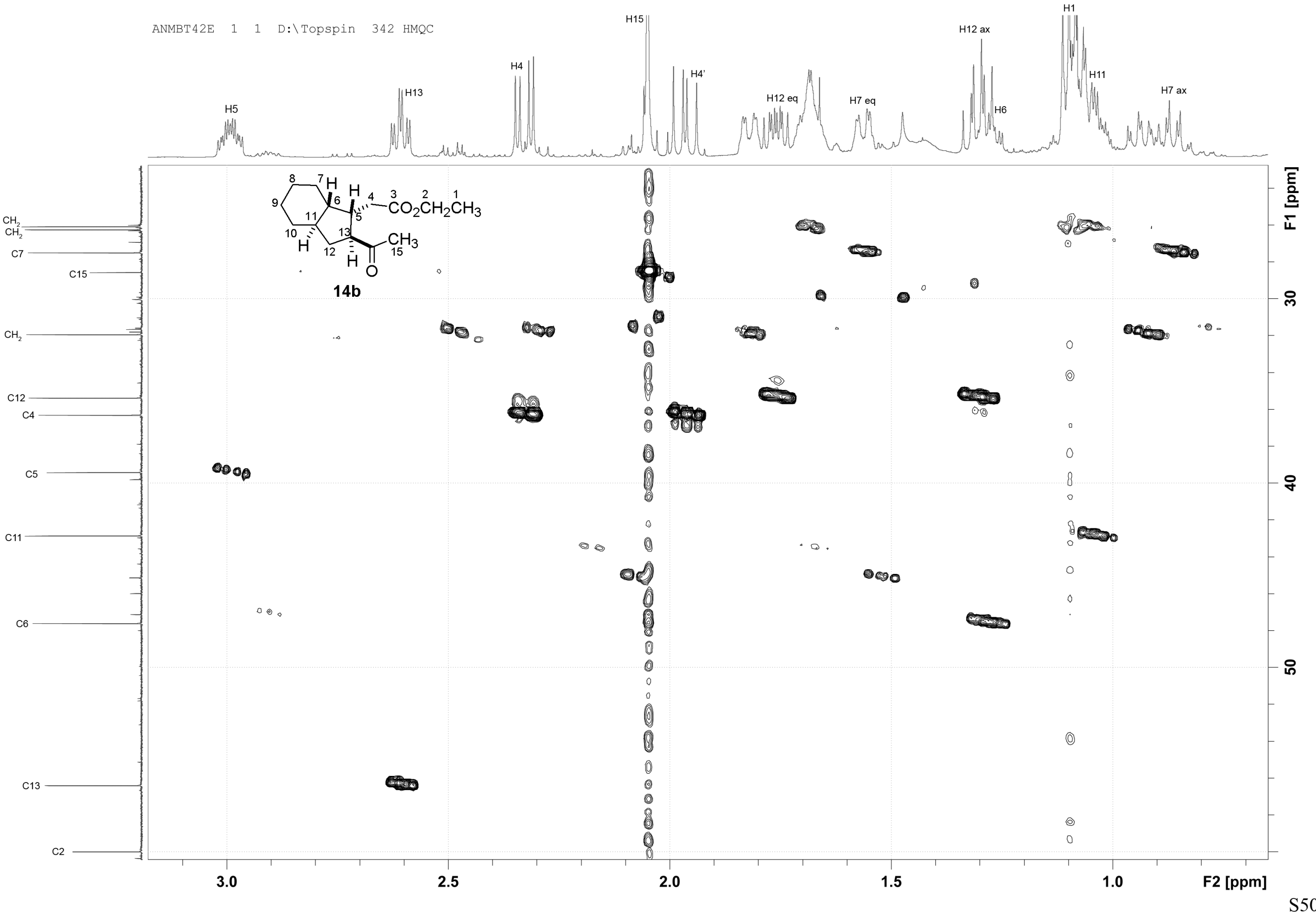


ANKBT42E 111 D: $\backslash$ Topspin 342 ROESY Tmix $150 \mathrm{sec}$ 